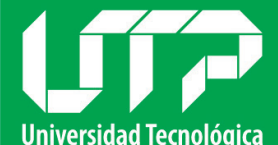
de Pereira

\title{
Croquis digitales: Urbanismos ciudadanos en Pereira
}
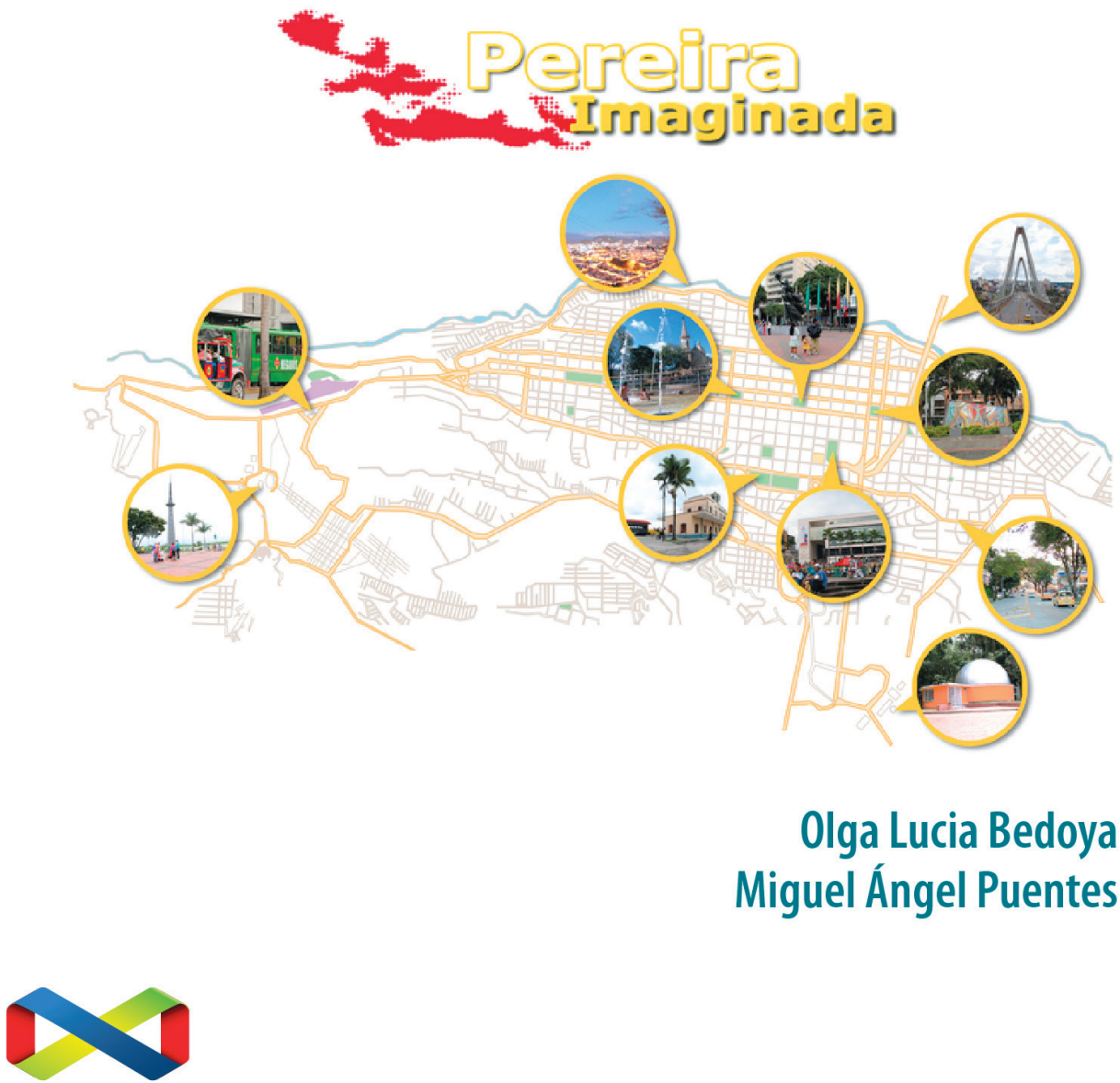

Editorial UTP 



\title{
Croquis digitales: Urbanismos ciudadanos en Pereira
}

\author{
Olga Lucia Bedoya \\ Miguel Ángel Puentes
}

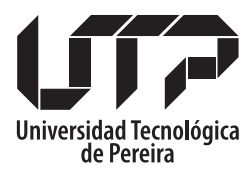

Facultad de Ciencias de la Educación

Colección Trabajos de Investigación

2018 


\section{Bedoya, Olga Lucia}

Croquis digitales : urbanismos ciudadanos en Pereira / Olga Lucia Bedoya y Miguel Ángel Puentes. - Pereira : Universidad Tecnológica de Pereira, 2018.

88 páginas : ilustrado. - (Colección Trabajos de Investigación)

ISBN: 978-958-722-334-7

1. Urbanismo - Pereira (Risaralda) - Colombia 2. Tecnología de la información - Aspectos sociales 3. Sociología urbana 4. Plataformas digitales

CDD 307.7986132

(C) Universidad Tecnológica de Pereira

1ra edición, 2018

ISBN: Obra independiente: 978-958-722-334-7

Título: Croquis digitales: Urbanismos ciudadanos en Pereira Proyecto de investigación: PEREIRA IMAGINADA: POR LOS CROQUIS DIGITALES DE LOS CIUDADANOS, con código 4-16-2.

Editorial Universidad Tecnológica de Pereira

Luis Miguel Vargas Valencia

luismvargas@utp.edu.co

Tel: 3137381

Edificio 9 Biblioteca central “Jorge Roa Martínez" 9/N1/110

Cra 27 No. 10-02 Los Álamos

Pereira, Colombia

www.utp.edu.co

\section{Montaje y producción:}

Universidad Tecnológica de Pereira

Centro de Recursos Informáticos y Educativos CRIE 




\section{CONTENIDO}

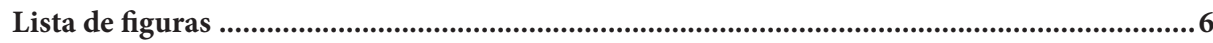

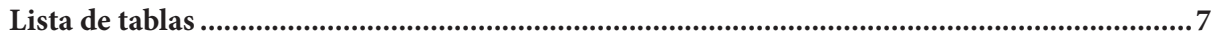

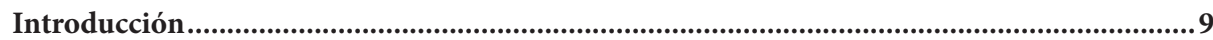

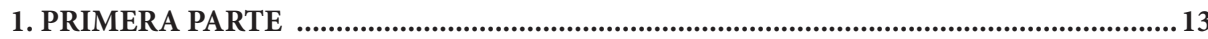

Recorrido investigativo: los urbanismos ciudadanos en la ciudad de Pereira ................... 15

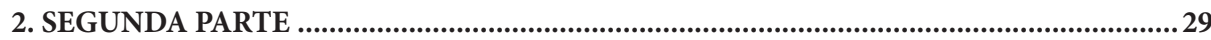

Socialización de la investigación Pereira imaginada. Construcción de

la multiplataforma virtual: por los croquis digitales de Pereira ......................................31

2.1. Experiencias en la relación contenidos

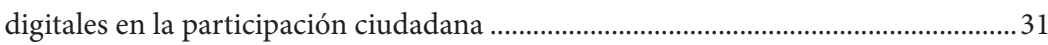

2.2. Metodología de construcción de la multiplataforma virtual........................................37

2.2.1. Fase 1: uso de la información de Pereira imaginada y su actualización ........................38

2.2.2. Fase 2: diseño e implementación de la plataforma virtual........................................... 43

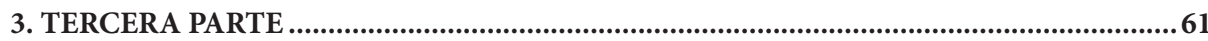

Resultados: croquis de la ciudad de Pereira .........................................................................63

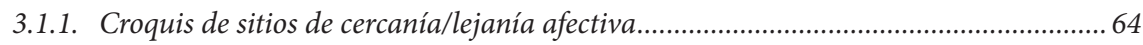

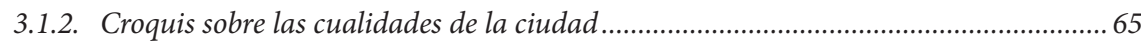

3.1.3. Croquis de calificaciones sobre los servicios para el ciudadano ......................................66

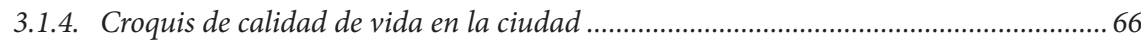

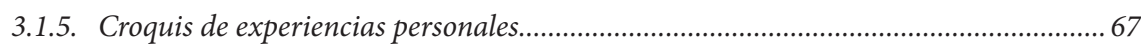

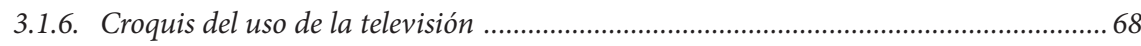

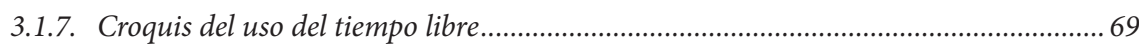

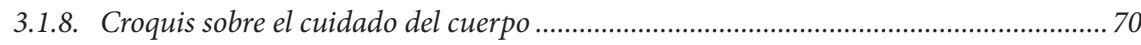

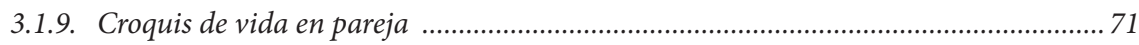

3.1.10. Croquis de experiencia personal del uso de la ciudad ................................................ 71

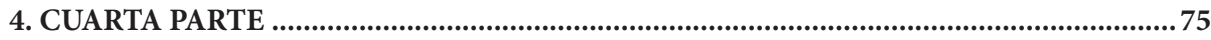

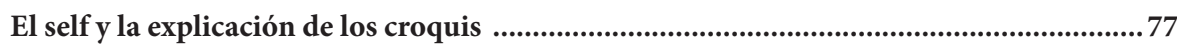

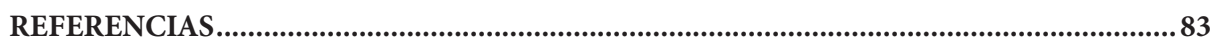

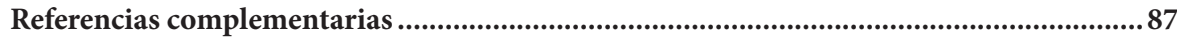




\section{LISTA DE FIGURAS}

Figura 1: Esquema de las categorías y subcategorías de la teoría de imaginarios urbanos............ 18

Figura 2: Esquema de las estructura de los LivingLab y MediaLab y ViveLab .36

Figura 3: Fotografías de categorías y subcategorías de la teoría de imaginarios urbanos: (a) área ciudad; (b) área ciudadanos; (c) área otredades 43

Figura 4: Fotografías la categorización manual de la información .44

Figura 5: Captura de pantalla de la primera categorización digital de la información .44

Figura 6: Fotografías del proceso de diseño de la propuesta visual:

(a) maquetación de la página principal; (b) maquetación de la pantalla escenarios; (c) maquetación del menú

Figura 7: Captura de pantalla de una parte de la base de datos del formulario base Ciudades Imaginadas

Figura 8: Captura de pantalla de la organización de la información, por escenario y por técnica

Figura 9: (a) y (b): Diseño de la propuesta visual. (a) maquetación del cabezote;

(b) maquetación de la página principal

Figura 10: Diseño de la propuesta visual: (a) maquetación de íconos del menú circular; (b) descripción del menú circular.

Figura 11: Diseño de la propuesta visual: (a) maquetación de la página de videos;

(b) maquetación de la página de paisajes sonoros

Figura 12: Diseño de la propuesta visual: (a) datos del usuario que está accediendo a la plataforma; (b) formato de pregunta y respuesta de la encuesta;

(c) resultados estadísticos .53

Figura 13: Cruce del río La Vieja. .54

Figura 14: Diseño de la propuesta visual: (a) histogramas de la base de datos

(b) generador de reportes de la base de datos. .56

Figura 15: Esquema de análisis de datos .64

Figura 16: Croquis de sitios de cercanía/lejanía afectiva. .64

Figura 17: Croquis de las cualidades de la ciudad. .65

Figura 18: Croquis de las calificaciones de los servicios para los ciudadanos 66

Figura 19: Croquis de calidad de vida .67 


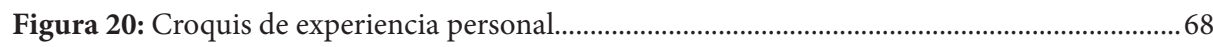

Figura 21: Croquis de rutinas alrededor del uso de la televisión .....................................................69

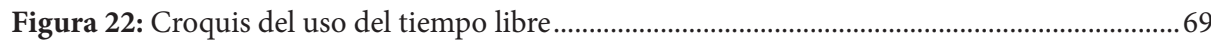

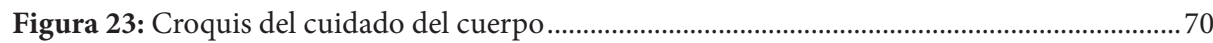

Figura 24: Croquis de vida en pareja …………………................................................................. 71

Figura 25: Croquis de experiencia personal en el uso de la ciudad. .................................................. 72

\section{LISTA DE TABLAS}

Tabla 1: Trabajos de grado desarrollados en el marco

del Semillero de Investigación en Comunicación Educativa..........................................................16

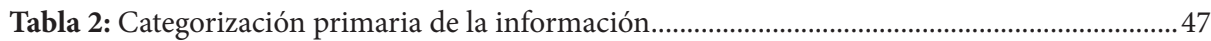





\section{Introducción}

Los lectores del presente texto, encontraran una narrativa que funde los resultados de investigaciones anteriores (2009-2017) sobre la ciudad, titulada Pereira Imaginada (muy breve dado que en el libro con el mismo nombre se presentaron los resultados ampliamente), y una estrategia de socialización-apropiación-consulta de dichos contenidos, titulada Croquis Digitales: urbanismos ciudadanos en Pereira.

En cuanto a las investigaciones, sólo damos un breve resumen, como enlace para que se comprenda el origen de la estrategia, pues existe un libro, Pereira Imaginada y tesis de maestría que recogen en su totalidad los resultados de la indagación.

La estrategia de divulgación-apropiación-consulta, es una plataforma multimedial que contiene las percepciones de los ciudadanos sobre las cualidades, calificaciones, escenarios, temporalidades, marcas, rutinas, y otredades sobre la ciudad de Pereira, expuesta a través de fotografías, videos, sonidos. Así mismo, se inserta el formulario base de las ciudades imaginadas, metodología tomada de los Imaginarios Urbanos propuesto por el investigador colombiano, Armando Silva (2005) con el objetivo de seguir obteniendo información de la ciudad, a medida que se navega por la plataforma. Su forma estética es amigable para el usuario: http://pereiraimaginada.utp. edu.co/(al entrar puede dar clic en X, para evitar la explicación que esta en el video); https://www.youtube.com/watch?v=Chd_qMkNXPs\&t=9s, que muestran videos sobre los croquis.

En general en YouTube con la frase "Pereira Imaginada", encontraran las producciones y visualizaciones de los croquis. Allí podrán observar, las dinámicas, cambios de la ciudad y sus urbanismos, lo que se convierte en memoria de ciudad, en estos momentos de tanta volatilidad de la vida urbana.

Teóricamente, los conceptos del investigador Armando Silva como, imaginarios urbanos, fantasmas, emblemas ciudadanos, croquis (imágenes mentales y afectivas de lugares, personajes, situaciones, vivencias, evocaciones), las cualidades, calificaciones, escenarios, temporalidades, marcas, rutinas, y otredades, han sido la base para 
comprender y organizar la información de la ciudad.

El objetivo del proyecto de Croquis Digitales: urbanismos ciudadanos en Pereira, fue construir una estrategia de comunicación interactiva con los resultados de la investigación Pereira Imaginada e implementar una prueba de usabilidad.

La finalidad, fue socializar la información que se ha acumulado por varios años de la ciudad y a su vez, lograr una actualización permanente de la misma, a través de la huella que van dejando los ciudadanos en la medida que la usan.

La metodología para construir la herramienta, fue realizar, en primer momento, un diseño y maqueta manual, con el contenido de la investigación, y luego se pasó a una forma digital, con la inclusión del formulario base de preguntas. En el aparte de este ítem en el texto, se detalla el procedimiento.

El contenido del presente texto, se estructura a partir de cuatro partes: la parte I, contiene una presentación general de las investigaciones anteriores sobre Pereira Imaginada, así como el estado de la cuestión, el cual trata del enfoque antropológico donde se ubican estos estudios urbanos; igualmente, artículos donde se trata en particular temas relacionados con la idea de croquis, aunque no usen dicho concepto.

La parte II, explicita toda la construcción de la metodología mediante la cual se llevó a cabo la construcción de la estrategia comunicativa digital.

La parte III, da cuenta de los resultados de la prueba de usabilidad de la herramienta y su análisis.

Finalmente, la parte IV, intenta dar una explicación desde la idea del Self (término del inglés que funde el Yo/mí, en uno solo, en español sería una idea de dos YO en uno pero no expresa la misma idea), de los croquis. Para entender lo que se quiere decir allí lo ponemos en pregunta: ¿por qué en una misma persona se funde lo que recibe colectivamente y al mismo tiempo su impronta personal?

Con esta introducción, esperamos que el lector se familiarice con el contenido que encontrará en el texto que ponemos a su disposición. 




\section{PRIMERA PARTE}





\section{Recorrido investigativo: Los urbanismos ciudadanos en la ciudad de Pereira}

El presente texto es producto del proyecto de innovación titulado Pereira Imaginada: por los croquis digitales, iniciativa financiada por la Universidad Tecnológica de Pereira (UTP) (2016-2017). El objetivo fundamental de la propuesta fue adaptar los contenidos de la investigación sobre Pereira Imaginada ${ }^{1}$ (cualidades, calificaciones, escenarios, temporalidades, marcas, rutinas, otredades) a un lenguaje digital. Su intención era poner a disposición de un grupo de personas de la ciudad (estudiantes, ciudadanos del común), dicha estrategia comunicativa, para después analizar los resultados arrojados por el ejercicio.

El sentido general del proyecto fue darle una aplicación real y concreta a la gran cantidad de información que diversos procesos investigativos han producido sobre Pereira entre 2009 y 2017. Con ello se pretende no solo hacer una apropiación social del conocimiento, sino también lograr la retroalimentación a través de las preguntas incluidas en ese lenguaje digital. La novedad de la iniciativa radica en la sincronicidad del proceso de retroalimentación (en tiempo real), toda vez que las preguntas se responden a medida que se recorre la estrategia divulgativa.

La primera parte del texto se dedica a presentar un breve recorrido por los temas investigados en la ciudad entre 1999 y 2017. El proceso culmina con una propuesta comunicativo-digital para el tratamiento de los datos, producto que constituye el abrebocas de la estrategia (ver segunda parte).

1. Pereira Imaginada es un proyecto inscrito en el macroproyecto de Ciudades Imaginadas, liderado por el investigador colombiano Armando Silva Téllez. Producto de ese trabajo investigativo se publica el libro Pereira Imaginada (Bedoya, 2009), el cual recoge las percepciones de los pereiranos sobre la ciudad, los ciudadanos y las otredades, al respecto de las temporalidades, las cualidades, las calificaciones, los escenarios, las marcas, las rutinas y las otredades de su ciudad. 
Elgrupo de investigación en Comunicación Educativa, en su línea de investigación «La Comunicación y la Educación en procesos de transformación cultural. Ciudad y Comunicación», tiene sus orígenes en 1997, año en el que inicia su carrera investigativa en el campo de interés. El grupo se encuentra posicionado actualmente en categoría A, en el sistema de clasificación de Colciencias. A comienzos de 1999 se publica el texto Imaginario Femenino y Ciudad: Pereira y su evocación de mujer, producto que es coproducido por Tercer Mundo Editores y la UTP. Este texto contiene los temores, las expectativas, los sueños y las maneras de usar y evocar la ciudad por parte de los pereiranos. Posteriormente se lanza la publicación de la investigación Paradoja de la ciudadanía en Pereira: entre los ciudadanos jurídicos y los itinerantes (2001-2003) (2004), donde se indagó sobre el tipo de ciudadano que recreaba la prensa local (Diario del Otún y La Tarde) y se preguntó sobre cuáles eran sus esquemas observacionales. El objetivo fundamental fue complejizar la categoría ciudadano que era recreada a través de la prensa local de Pereira. Con el proyecto de investigación «Paradoja de la ciudadanía en Pereira: entre los ciudadanos jurídicos y los itinerantes (2001-2003)» se crea el primer Semillero de Investigación en Comunicación Educativa inscrito en Colciencias. La iniciativa del semillero comienza así sus labores con el desarrollo de cuatro trabajos de grado (Tabla 1 ):

Tabla 1. Trabajos de grado desarrollados en el marco del Semillero de Investigación en Comunicación Educativa

\section{Nombre del trabajo de grado}

Paradoja de la ciudadanía en Pereira: Entre los Ciudadanos Jurídicos y los Itinerantes (2001 2003)

La Ciudad Planeada / La Ciudad No Planeada: Una re-re-recreación desde la prensa local (Diario del Otún y La Tarde) 2003

La intervención social: problematización del caso pereirano
Tema de investigación

¿Cómo construir una ciudad ignorando lo que es, en aras de lo que no es?
El proyecto indagó sobre el concepto de realidad y sobre la relación sujeto-objeto y verdad que subyacen a los procesos de intervención social

¿El ciudadano está directamente relacionado con el proyecto de ciudad real o, por el contrario, desde allí estaría por fuera, puesto que sería una relación del ciudadano con una ciudad real?

Pereira recreada desde el imaginario del que escribe en la prensa local: una mirada desde el lenguaje (La Tarde y el Diario del Otún 20012003)
¿Cómo visibilizar la recreación de la ciudad a partir del compromiso (posición subjetiva) del locutor de la página de opinión? ¿En qué medida, desde el lenguaje, se direcciona un determinado tipo de ciudad?

Fuente: elaboración propia 
Entre los años 2006 y 2007, el grupo de investigación en Comunicación Educativa desarrolló la cuarta fase de investigación de Pereira Imaginada con el proyecto «Cartografía imaginaria de la ciudad de Pereira: percepciones ciudadanas», proyecto inscrito en el centro de investigaciones de la UTP. El objetivo fundamental del proyecto era elaborar una «cartografía imaginaria de la ciudad de Pereira desde las formas de percepción ciudadana (1999-2006)» (Bedoya et.,2007). Lo que se buscaba era examinar las continuidades y rupturas que presentaba el imaginario de ciudad en los ciudadanos de Pereira frente al estudio adelantado por la Maestría en Comunicación Educativa en el período 1997-1999. Con ese propósito se realiza un paralelo (continuidades vs. emergencias) entre los nuevos hallazgos y lo registrado en la primera fase de la investigación. El proceso culminó con la publicación del libro Imaginario femenino y ciudad. Pereira y su evocación de mujer, 1997-1999 (Bedoya et., 1999).

En el 2009 se desarrolló la quinta fase de la investigación. En esta ocasión, el macroproyecto de investigación Pereira Imaginada: 2009-2014 se planteó como objetivo fundamental develar los imaginarios de la ciudad de Pereira a partir de las formas de percepción ciudadana. El trabajo investigativo de esta fase culminó con la producción de cuarenta y dos tesis de maestría, desarrolladas por los maestrandos que participaron como auxiliares de investigación. Los resultados de esta investigación fueron publicados en el libro Pereira Imaginada (Bedoya, 2011), cuyo editor y coordinador general fue Armando Silva Téllez.

Este último texto se valió de la metodología que Armando Silva desarrolló para procurar aprehender las ciudades imaginadas. La metodología se inscribe filosóficamente en una visión triádica del mundo, que se apoya en el pensamiento de semiótico de Charles Sanders Peirce (1893-1913) y la pluralidad del YO, en Sigmund Freud (1893-1895). Silva propone un formulario base de 82 preguntas y subpreguntas, que despliega en tres categorías y subcategorías: ciudad: cualidades, calificaciones y escenarios; ciudadano: temporalidades, marcas y rutinas, y otredades: afinidad, lejanía $\mathrm{y}$ anhelos. 
Figura 1. Esquema de las categorías y subcategorías de la teoría de imaginarios urbanos

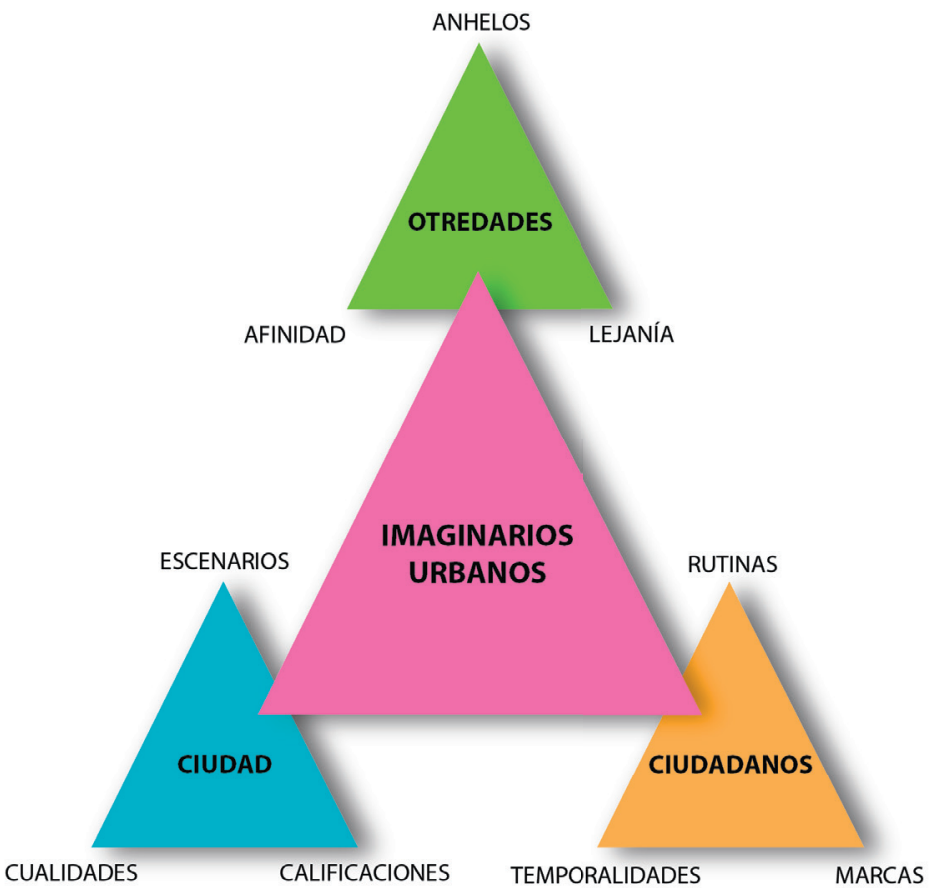

Fuente: Miguel Puentes

En cuanto a la visión triádica, Peirce considera el fenómeno (phaneron) como la relación entre la primeridad, la segundidad y la terceridad. Desde esta perspectiva fenomenológica, la primeridad está en el campo de las sensaciones, la segundidad en el de la reacción o "lucha" entre esas sensaciones y los objetos de la conciencia o externos, y la terceridad en el mundo de la historia o de las leyes donde esos fenómenos tienen sentido (Houser, Kloesel (2012). Así las cosas, los estudios sobre el phaneron se explican a partir de estas relaciones. Para nuestro caso, léase ciudad > ciudadano $>$ otredades, donde las emociones, las referencias a objetos o situaciones y lo que se infiere de esa relación marcan la lectura de una determinada información.

El campo teórico donde se inscriben tanto los estudios urbanos de Silva como los del grupo de investigación es el antropológico, especialmente en lo referente a los estudios de ciudad o urbanos. En la postura antropológica se dan diferentes énfasis en los análisis de lo urbano.

Ahora bien, al respecto del estado de la cuestión de los estudios de ciudad - y para pasar de la ciudad física a la de los urbanismos ciudadanos -, Valencia y Jaramillo (2014), en su trabajo Estado de la cuestión de los estudios de ciudad: El caso de las vertientes de la antropología urbana en México y Colombia/GICE, plantean lo siguiente:

Las ciudades como fenómeno de investigación han sido abordadas por diversas disciplinas, entre ellas la sociología, la historia, la comunicación, los estudios culturales, 
[los imaginarios urbanos] e indiscutiblemente la antropología urbana. Esta última, adscrita fundacionalmente a la Escuela de Chicago y posteriormente ampliada desde la corriente británica y la corriente francesa, ha marcado algunas influencias teóricas en el estudio de las ciudades en América Latina. Ejemplo de ello, es lo planteado por autores como: Signorelli (1999), Licona (2003), Silva (2004), Bedoya (2004), Portal y Barraza (2005), Canclini (2005), Reguillo (2005) (pp. 1-2).

Y en el mismo trabajo, pero ahora con relación a las escuelas y corrientes teóricas que asumen a la ciudad como objeto de estudio, Valencia y Jaramillo (2014, pp. 3-6) observan:

\section{Corrientes teóricas: Escuela de Chicago, de Manchester, y la corriente francesa}

En el caso de los Estados Unidos, la preocupación por la ciudad nace articulada, como lo aprendimos con Signorelli (1999), al crecimiento de las ciudades, específicamente Chicago, que creció vertiginosamente entre finales del siglo XIX y comienzos del siglo $\mathrm{XX}$, como producto de la propia migración interna y de algunos países europeos. Es así que en Chicago nace el primer centro de estudios urbanos conocido como la Escuela de Chicago, reconocido no solo por haber fundado la antropología urbana y la sociología urbana, sino por "haber tematizado a la ciudad como tal" (Signorelli, 1999, p. 67), y haber incluido una metodología antropológica en los estudios urbanos.

Esta Escuela fundada en 1920 conservará hasta finales de 1940 la concepción de asentamiento humano como comunidad, perspectiva arraigada en un fuerte apego territorial y en la demarcación física del mismo, a partir de lo cual se define la ciudad con criterios geográfico-espaciales. Entre 1950 y 1960 emerge uno de los aspectos de mayor trascendencia para esta escuela, conocido con el nombre de antropología urbana y caracterizada por dos orientaciones: “antropología en la ciudad” y "antropología de la ciudad”. La primera orientación tiene por objeto recuperar las tradiciones de:

(...) familia y parentesco, grupos locales y vecindario, tradiciones y rituales, todos objetos que permitían al antropólogo continuar utilizando los instrumentos conceptuales y metodológicos que la tradición de su disciplina le ofrecía. Fue una larga cosecha de investigaciones que tuvieron el mérito, junto con algunas orientaciones de la microsociología, de evidenciar cómo las formas tradicionales de la estructura social y del patrimonio cultural no se disuelven en el contexto urbano (Signorelli, 1999, p. 70).

"La antropología en la ciudad no llega muy lejos", a falta de capacidad teórica para abordar el fenómeno urbano, en lugar de estudiar la ciudad, estudia cómo los recién llegados se adaptan a esta; y se producen una serie de investigaciones bajo el controvertido concepto de "cultura de la pobreza" de Oscar Lewis.

La segunda orientación de la antropología urbana, "antropología de la ciudad" se puede entender en dos sentidos. Por un lado, la ciudad como realidad espacial y social que condiciona actitudes y comportamientos, y por el otro, la ciudad como realidad espacial y social producto de las relaciones sociales (Signorelli, 1999, p. 72). 
A diferencia de la Escuela de Chicago, en Gran Bretaña el estudio de la ciudad nace en relación al crecimiento de las ciudades africanas, los procesos de urbanización y la persistencia del tribalismo/destribalización del inmigrante en la llegada a la ciudad; las problemáticas enunciadas configuran el objeto de investigación de institutos como el "Rhodes-Livingstone Institute de Lusaka (Zambia)", el "East African Institute of Social Research de Kampala" y la "Escuela de Manchester" influenciada por Max Gluckmann, reconocido director del Institute de Lusaka, quien se traslada en la segunda mitad del siglo XX a la Universidad de Manchester.

En el caso del Instituto de Lusaka, por ejemplo su objeto de interés se centra en el crecimiento de las ciudades africanas, específicamente, las llamadas Cinturón del Cobre, exaltando allí los procesos de inmigración campo-ciudad; y en el caso de la Escuela de Manchester su objeto de investigación son los procesos, los recursos y las estrategias que ofrece la cultura tradicional del emigrado para la integración a las ciudades (Signorelli, 1999, pp. 73-74).

Entre las contribuciones más significativas de la Escuela de Manchester se conoce: la construcción de nuevos instrumentos para el trabajo en terreno, la incorporación de nuevas propuestas metodológicas como el análisis situacional con su concepto de $\mathrm{red}^{2}$, a partir del cual se intentan explicar los cambios en las sociedades tradicionales, los mecanismos de articulación a las sociedades complejas, y el surgimiento de los "Cultural Studies" guiados por una orientación marxista, y dedicados al análisis del rol de la cultura en las relaciones sociales. Este último, plantea por primera vez, aunque de manera poco explorada, una clasificación entre espacios y estructuras de la ciudad; donde las pantallas audiovisuales, el cine, los anuncios publicitarios se conciben como espacios cargados de significado en el contexto de la construcción de ciudad.

Ahora bien, a diferencia de la Escuela de Chicago, del grupo de estudiosos del Instituto de Lusaka, del Instituto de Kampala y de la Escuela de Manchester, la corriente francesa es más consistente en sus aportaciones teóricas en este ámbito.

La corriente francesa se caracteriza en primer lugar por la influencia del estructuralismo de Lévi-Strauss, quien retoma de Durkheim la diferencia entre "sociedades a solidaridad mecánica" y "sociedades a solidaridad orgánica", construyendo a partir de esta, su distinción entre "sociedades frías" y "sociedades calientes", y en segundo lugar, por las contribuciones de Henry Lefebvre, Gerard Althabe, Chombar de Lauwer, entre otros autores.

La configuración teórica de George Balandier es una de las contribuciones de la antropología urbana francesa, específicamente la discusión en torno a la fundación del poder sobre bases diferentes a la violencia y los medios de producción, en este caso sobre las relaciones de parentesco, de prestigio y capital mítico e ideológico de un grupo.

2. En palabras textuales de Molina (2001) «el concepto de red social fue desarrollado por la antropología británica a partir de la Segunda Guerra Mundial como respuesta a las limitaciones del estructural-funcionalismo para explicar las situaciones de cambios en las sociedades tradicionales y los mecanismos de articulación de las sociedades complejas».

Nota al pie que pertenece al original. 
La contribución de Henry Lefebvre a la teoría de las representaciones, emerge de su inquietud por la vida cotidiana, y es plasmada a través de la relación "vivido"/"concebido", no como una relación disyuntiva, que en el aletargado sueño de la razón, del binarismo occidental, nos condujera a pensar en términos de razón o emoción, sujeto u objeto, cuerpo o espíritu, consciente o inconsciente, presencia o ausencia, etc., sino como un par de oposición complementaria, que simultáneamente evoca la constante presencia de la diferencia acompañada de la imposibilidad de la separación.

De otro lado, Valencia y Jaramillo (2014, pp. 7-8) advierten también que las investigaciones del mexicano Néstor García Canclini (2005), se pronuncian frente a la incidencia de las nuevas tecnologías en la desaparición y muerte de las ciudades, en cuanto que crean otras experiencias y nuevos imaginarios, apuntando hacia lo policéntrico en detrimento de lo monocéntrico. En este orden de ideas, Signorelli, habla de la "ciudad cableada" (1999, p. 86-88).

En la "La antropología en México y la Cuestión Urbana", Néstor García Canclini (2005) presenta los "tres aspectos claves de las ciudades contemporáneas". La "heterogeneidad"; la "multiculturalidad" y la "megalópolis", los cuales son los componentes de la ciudad actual.

Amanda Signorelli (1999), en "Antropología Urbana", propone los siguientes elementos en la existencia de las ciudades: las diversidades entre ciudad y campo, entre las ciudades, y las diferencias internas de cada ciudad. Además, presenta un paralelo entre la concepción del "proyectista" (planificadores) y el "usuario" (público de ciudadanos), al concebir la casa, el barrio y el espacio [como escenarios de estudio] (Valencia y Jaramillo 2014, pp. 13-15).

Rossana Reguillo (2005) en "Ciudad, riesgo y malestares. Hacia una antropología del acontecimiento", examina tres corrientes en la antropología urbana en México: una llamada "antropología del desastre"; la otra, "antropología de las violencias urbanas"; finalmente, "antropología de la sociabilidad urbana”. Y propone, "ejes y campos estratégicos para la antropología del acontecimiento". Con respecto a este último muestra tres categorías: el "actor urbano", la "gestión del riesgo" y la "ciudad representada". En el "actor urbano", examina los diferentes modos de manifestación de los actores de un desastre, o un hecho violento o una acción ciudadana. En "gestión del riesgo", entrevé la brecha ente los saberes versados y los del ciudadano común, en un acontecimiento urbano. Y en "ciudad representada", se pregunta por el rol de los medios masivos de comunicación en la representación y construcción del acontecimiento.

Ahora bien, elaborado el recorrido por la trayectoria de los estudios de ciudad, observamos como a partir del año 2000 se incluye por primera vez en los estudios urbanos el "punto de vista ciudadano". En este sentido, Ernesto Licona Valencia ${ }^{3}$, en el trabajo titulado "Dibujos de un barrio: entre el signo y el ícono, una reflexión sobre imaginarios urbanos", propone conocer como es "recordado y recorrido (física y

3. Investigador del Colegio de Antropología Social de la Benemérita Autónoma de Puebla, México. Actualmente coordinador del Centro de Estudios de la ciudad.

Nota al pie que pertenece al original. 
mentalmente)" (2003, p. 313), Tacubaya por sus habitantes. Para ello, el autor recurre a la categoría conceptual de memoria y a la forma como esta se teje con la oralidad y el trazo gráfico en la construcción de una imagen y posteriormente de un imaginario.

La información principal en esta investigación se obtiene a través de las evocaciones y los trazos de los tacubayenses al dibujar su territorio/espacio, en los cuales se expresan los "puntos de vista" de la población consultada. Licona recurre a la categoría "punto de vista" del investigador colombiano Armando Silva leyendo en ella "una serie de estrategias discursivas por las cuales los ciudadanos narran las historias de su ciudad, aun cuando tales relatos puedan, igualmente, ser representados en imágenes visuales" (2003, p. 323), a fin de conocer como los consultados reseñan a Tacubaya y como es reconstruida imaginariamente.

A nivel nacional, Valencia y Jaramillo (2014, pp. 18) reseñan los trabajos de Armando Silva, quien propone una "antropología del deseo ciudadano":

(...) a finales 1990, [Silva] propone desplazar la ciudad del lugar geográfico, físico, visual (como es el caso de los graffitis y las vitrinas), a una ciudad no visible, a una ciudad desde la percepción ciudadana, del "deseo" ciudadano. Esta es la apuesta que cristaliza Silva (2004) en la metodología denominada "imaginarios urbanos", de la investigación: "colección ciudades imaginadas", organizada en trece equipos en ciudades de América Latina y España (Asunción, Barcelona, Bogotá, Buenos Aires, Caracas, La Paz, Lima, México, Montevideo, Panamá, Quito, Santiago de Chile, Sao Paulo), que buscaba captar la ciudad de los ciudadanos, la/s ciudad/des que llevan en sus mentes y en los modos de vida, y aportar como lo narra el autor elementos a la definición de las políticas públicas de lo urbano, desde la inclusión de la perspectiva ciudadana. Así, entonces, la Antropología del deseo ciudadano, examina las inter-acciones humanas y, por tanto, las relaciones psicológicas, sociales o incluso de interacción con el paisaje o hasta la captación de memorias grupales, las cuales también pueden ser parte de ese renovado sentido ciudadano (Silva, 2007, p. 36).

La "metodología de imaginaros urbanos" apropiada en el proyecto "Culturas urbanas en América Latina y España desde sus imaginarios sociales"4, tiene como objetivo captar los "croquis afectivos" o las distintas formas de ciudad existentes en las mentes de los ciudadanos, según "puntos de vista", establecer comparaciones entre los fenómenos, los modos de ser urbanos a partir de las percepciones ciudadanas y

4. Este proyecto es financiado por el Convenio Andrés Bello, a partir del año 1998, cuando se le propone al investigador colombiano Armando Silva Téllez, aplicar en trece ciudades de América Latina y España los planteamientos expuestos en su libro titulado Imaginarios Urbanos (1992), en donde se mezcla una metodología que combina los datos oficiales de cada ciudad, con las percepciones del público de ciudadanos.

Nota al pie que pertenece al original.

5. En la metodología de Imaginarios Urbanos los "puntos de vista ciudadanos" corresponden a filtros desde donde se muestran y perciben las ciudades, Silva (2004), identifica nueve "puntos de vista": "lugar de vivienda", "trabajo", "actividad”, "nivel socioeconómico", edad”, "género", "origen”, y "personas con quien vive", de los cuales el "nivel socioeconómico", "edad" y "género", se leen como los tres "puntos de vista determinantes.

Nota al pie que pertenece al original. 
explicitar el proceso de trabajo en cada una de las ciudades estudiadas.

Con el propósito de conocer las distintas ciudades y los modos de ser urbanos que llevan en sus mentes los ciudadanos de las trece ciudades estudiadas ${ }^{6}$, la propuesta metodológica del investigador Armando Silva Téllez, se estructura a partir de la lógica trial peirceana en tres tricotomías: ciudad, ciudadanos y otredades. La primera tricotomía busca develar los elementos y los signos que identifican a cada ciudad, a través de las cualidades, calificaciones y escenarios urbanos. La segunda tricotomía trata de comprender las maneras como los ciudadanos construyen sus realidades, mediante las temporalidades, marcas y rutinas. Y la tercera tricotomía indaga por la forma como nos ven y como vemos a los otros, a partir de las ciudades cercanas, lejanas y anheladas.

Las investigaciones realizadas sobre Pereira imaginada - y que nos sirvieron de base para construir una plataforma virtual para socializar y validar la informacióntomaron como teoría el "paradigma de la ciudad imaginada". Acuñado por Silva, el término funciona para plantear $<<$ que es posible hacer la distinción entre la ciudad de los arquitectos: la ciudad física, la ciudad de las edificaciones y de las calles, de la ciudad de los habitantes, de la comunicación, de lo urbano, de los anuncios y de los productos digitales o señales, como detonantes de acciones ciudadanas $>>$ (Silva, 2007). Ello exige, entonces, desplazarse desde el lugar geográfico, físico, tangible y visible (grafitis y vitrinas), a otro donde emerge una ciudad no visible: es la ciudad de los ciudadanos, y las ciudades que llevan en sus mentes. Una visión de estas características requiere trasladarse a la ciudad, pero desde la percepción ciudadana; hay que ir entonces a esa otra ciudad del deseo ciudadano que se vuelve colectivo. En este orden de ideas, ciudad, ciudadanos y otredades ${ }^{7}$ son las categorías que Silva propone para capturar los imaginarios.

Silva plantea el concepto de imaginario desde tres elementos constituyentes: como creación de la realidad social, como unidad entre imaginario-realidad y como entidad concebida en su dimensión dinámica y creativa-estética. El aporte del autor está en las dos últimas consideraciones.

En cuanto creación social, la realidad se opone a la tradicional concepción de pensarla como algo dado, estable, por fuera de la persona misma, quien solo la describe y mide. El debate se encuentra en las reflexiones de reconocidos académicos, entre los que se cuentan Maturana, 1997; Moran, 1990; Capra, 1998; Balandier, 1988; Berger y Luckmann, 1966; Fischer, 1997; Pintos, 1995; Putnam, 1988; Varela, 1988; Watzlawick, 1981 y 1988, y Luhmann, 1998. Estos autores muestran como en Occidente la realidad se ha concebido de una manera naturalizada, al proponer una perspectiva que la entiende como construcción social. Por lo tanto, defienden que la realidad es dinámica, se transforma, pues son las personas quienes la construyen, y en esa medida, pueden intervenir sobre sus resultados. En palabras de Watzlawick (1988):

6. A la fecha, el proyecto se ha desarrollado en 22 ciudades. Nota al pie que no pertenece al original.

7. En el texto Metodología sobre los imaginarios urbanos, Armando Silva (2004) presenta de forma sucinta las bases teóricas que sustentan el formulario base (82 preguntas), dirigido a capturar los imaginarios urbanos desde diferentes medios. 
(...) lo observado por el observador, los efectos retroactivos de la acción de observar, cuyo estatus y cuyo papel permanecen, sin embargo, en la oscuridad, se convierte en una parte influyente del sistema observado, lo que permite una nueva visión de la realidad: la realidad surge por medio de la comunicación (p. 67).

De la cita de Watzlawick resaltamos la inclusión de quien observa-crea una realidad en lo observado, lo que nos aparta de la idea de una objetividad pura en las construcciones.

Asimismo, al respecto de la discusión del papel de la sociología del conocimiento, Berger y Luckman (1966) plantean que:

¿Cómo es posible que la actividad humana (Handein) produzca un mundo de cosas (choses)? O sea, la apreciación adecuada de la "realidad sui generis" de la sociedad requiere indagar la manera como esta realidad está construida. Sostenemos que esa indagación es la tarea de la sociología del conocimiento (p. 35).

Es pues claro que Berger y Luckman enfatizan sobre el proceso de cómo los seres humanos producimos cosas y, por lo tanto, es necesario preguntarnos por eso. En ese sentido, incluyen la idea de vida cotidiana, entendida como esa situación necesaria para conectar lo que pensamos con lo que hacemos. Pero, al mismo tiempo, refieren que la vida se experimenta en niveles distintos, de proximidad y de alejamiento, tanto espacial como temporal. Así, lo más próximo a mi cercanía corporal y que me es accesible, está determinado por lo que hice, hago o haré, y, en consecuencia, puedo transformar. Las otras posibilidades, que no considero porque no son de mi interés próximo, quedan en la potencialidad.

Retomando la idea ya planteada sobre los elementos distintivos del concepto de imaginario de Silva, encontramos que el autor parte de la continuidad entre lo imaginario y la realidad, alejándose de la tradicional concepción que considerar lo primero como algo irreal y la segunda como real. Desde esta postura se evoca el término sinequismo de Charles Sanders Peirce (1893), que significa «la tendencia a considerar todo como continuo» Houser y Kloesel (2012):

El sinequismo niega toda diferencia inmensurable entre los fenómenos, y por la razón no puede haber diferencia inmensurable alguna entre la vigilia y el ensueño. Cuando uno está dormido, no está tan dormido como podría imaginar que está (...) tus prójimos son, en alguna medida, tú mismo y en mucha más medida que creerías (p. 51).

De esta manera, el imaginario comparte esta idea de continuidad entre lo real imaginado. El sinequismo de Peirce se observa en los planteamientos de Silva cuando este expresa que «real ya incluye lo imaginado. Es decir, no es posible que algo exista si no es imaginado» (comunicación personal, febrero 20 de 2015, p. 1), al tiempo que para referirse a los tres niveles de captación del imaginario (la inscripción psíquica, la social y la técnica de representación), Silva indica que van al unísono, interactuando al tiempo. El primer nivel se refiere al valor afectivo sobre el objeto referenciado; el segundo tiene que ver con las "culturas textualizadas", aquellas que no obedecen a las normas o códigos de las leyes, sino que se construyen con otras lógicas ciudadanas, y la tercera es la forma como logra manifestarse ese imaginario, suceso que depende de las épocas históricas. Complementa Silva que en una época se manifestaba el imaginario en la fotografía, luego en el cine, y hoy, en lo virtual, en cierta medida, pues los imaginarios se construyen desde los sujetos y no con códigos algorítmicos (Silva, 2007). 
Silva (2007) propone una noción particular de imaginario, al que define como un "proceso psíquico perceptivo cuando lo entendemos motivado por el deseo y cuando lo que atendemos no es su representación ni su descarga satisfactoria sino una forma de aprehender el mundo (...) esta idea incluye el proceso lógico hermenéutico, y analítico» (p. 91).

En la noción de imaginario que Silva propone, se puede destacar que lo psíquicoperceptivo es motivado por el deseo. No obstante, esa posición deseante es social, pues los imaginarios son colectivos (públicos), y por eso, su tratamiento se hace desde los "modos sociales de conocer". Este conocer, diríamos, toma forma desde el mundo experiencial directo e indirecto, y lo encarnado lo hace a través de los procesos sociales en los que estamos inmersos, que es por donde circulan imaginarios que, por lo general, se toman como verdades, y se actúa en concordancia con ellos. Sobre el particular, Silva (2007) continúa diciendo:

En consecuencia, entendemos que los imaginarios urbanos estudian las culturas ciudadanas y que sus investigaciones avanzan hacia la construcción de una teoría del sentir ciudadano como expresión de deseos hechos colectivos por su coincidencia en la búsqueda del mismo objeto. En rigor, son los imaginarios urbanos los que habitan a sus ciudadanos (p. 91).

De la cita de Silva se destaca la idea de cimentar una idea del sentir ciudadano, en cuanto vocera de los deseos fusionados grupalmente en pos de lo buscado. Pero el sentir ciudadano no lo entendemos como universal u homogéneo, sino como una expresión local textualizada culturalmente, como lo dice el mismo autor.

La teoría de imaginarios urbanos se materializa en tres aspectos, que representan lo que Silva (2007) denomina <<ciudad imaginada como modelo encarnado: i) la realidad existe, pero no el imaginario de ella $(\mathrm{R}>\mathrm{I})$; ii) el imaginario está presente, pero no su realidad empírica $(\mathrm{I}<\mathrm{R})$, y iii) el imaginario coincide con la realidad $(\mathrm{R}>\mathrm{I}<\mathrm{R})>>$ (p. 77).

En primera instancia está la ciudad, concebida desde un sentido físico e histórico. La categoría se divide a su vez en tres subcategorías: cualidades (posibilidad de ser ciudadano); calificaciones (conexión del ciudadano con los hechos de la ciudad), y escenarios (lugares del ciudadano para estar o imaginarse). En segundo lugar está la subcategoría ciudadano (construcciones de realidades urbanas), que se divide en temporalidades (tiempos dedicados a sus actividades en la ciudad); marcas (recuerdos, vivencias e imaginaciones futuras), y rutinas (lo que el ciudadano hace en su vida cotidiana). Finalmente está la categoría otredades, que se divide en tres ámbitos de estudio: cercanías, lejanías y anhelos de los ciudadanos (cómo imaginan que los ven sus vecinos; cómo creen que los ven sus vecinos; cuáles son sus anhelos).

Este es el panorama teórico que se ha empleado para leer la información recopilada durante estos años de investigación.

Como decíamos al principio, al tener tanta información de la ciudad, llega el momento de crear una estrategia de socialización y actualización in situ de los datos. Fue esta la oportunidad que nos llevó a diseñar y crear una multiplataforma digital, que inició su funcionamiento en el año 2017.

Exponemos a continuación tres aspectos fundamentales de esta iniciativa: a) la metodología de creación de la estrategia comunicativa, que parte de la información que sobre la ciudad y los urbanismos ciudadanos se ha recopilado durante los ejercicios de investigación 
precursores; b) la puesta en escena de dicha estrategia, y c) los croquis ${ }^{8}$ ciudadanos, que son el resultado de la interpretación de la información suministrada por las personas durante sus recorridos digitales.

Auscultando sobre la etimología y el uso del término mapa, encontramos en la tradición europea que mappa denotaba un lienzo con dibujos del mundo, con detalles geográficos finos. En otro sentido, en el diccionario de Francisco de Alvarado (1593), citado por Boone (1998), se dice que en Occidente, un mapa se distingue por su esencia pictórica, su organización espacial y sus elementos de precisión geométrica. En tanto que Silva entiende los mapas como "espacios geográficos delimitados por fronteras políticas y geográficas» (Silva, 2005, p. 20). Así entonces, desde sus diversas nociones, el mapa conlleva la idea de marcaciones físicas, geográficas y precisiones geométricas.

Ahora, si bien se encuentra relacionada con el concepto de mapa, la noción de croquis resulta entendida de otra manera. Según Silva (2004, p. 56), los croquis urbanos son vivencias del afecto ciudadano, que indican la forma como los ciudadanos viven la ciudad imaginariamente. Se destaca que para la construcción de los croquis priman el afecto y la inclinación ciudadana concreta por sobre las directrices de orden institucional, que se caracterizan por su perfil abstracto. Así entonces, los ciudadanos tienen un saber de lo urbano, no solo desde sus experiencias, sino de lo que escuchan, de lo que se transmite de generación en generación, de lo que han leído,etc. Por lo tanto, la ciudad se narra desde la heterogeneidad de estos conglomerados afectivos, desde las otredades: cómo se ven ellos, cómo ven a los otros y cómo creen que son vistos. Autores como Novikov hablan de geografía mental, de mapas afectivos o del paisaje emocional de la ciudad (El Futuro Es Apasionante, 2017); sin embargo, en dichos términos todavía permanece la idea de lo físico.

A partir de las orientaciones anteriores, nos propusimos indagar por los croquis que los ciudadanos de Pereira identificaban en la ciudad. La herramienta seleccionada es una plataforma virtual que permite a los ciudadanos interactuar con los resultados arrojados por las investigaciones sobre Pereira imaginada en el periodo 2009-2017. La mediación para la interacción es una pantalla táctil donde se reproducen fotografías $3 \mathrm{D}$, videos y sonidos, al tiempo que los participantes enfrentan las preguntas del formulario base propuesto por Silva.

La experiencia investigativa sobre los imaginarios urbanos exigió que los investigadores levantaran y sistematizaran información de diversa índole, cumpliendo así con una labor que Silva denomina los archivos ciudadanos. Se trata de formularios de preguntas, libros, artículos, tesis de maestría (alrededor de 100), videos, fotos, archivos sonoros, clips audiovisuales, entre otros registros. Todo este material, recopilado entre los años 1999 y 2017, conforma una riqueza documental considerable, que nos sirve como base para dar cuenta de los croquis de los ciudadanos de Pereira del 2017, los cuales están sustentados en la comparación de los resultados de los trabajos de 2009, de 2014 y de 2017. Así pues, este libro recoge un consolidado de casi 20 años de trabajo.

8. La idea de croquis es una categoría que se opone a la de mapa porque da cuenta de la creación de redes afectivas antes que física, por lo tanto, trasciende estos espacios. 


SEGUNDA PARTE 



\section{Socialización de la investigación Pereira imaginada. Construcción de la multiplataforma virtual: por los croquis digitales de Pereira}

Una vez expuesta la filosofía que subyace en nuestras investigaciones y ya presentado el enfoque teórico-antropológico en el cual se enmarcan los estudios, así como la concepción de imaginarios urbanos y croquis ciudadanos, este apartado presenta la metodología de la multiplataforma virtual, la puesta en escena de la plataforma y un análisis de lo obtenido, uniendo el proceso investigativo con una socializaciónactualización de los imaginarios urbanos.

\subsection{Experiencias en la relación contenidos digitales en la participación ciudadana}

Iniciamos haciendo una pesquisa de las plataformas virtuales utilizadas para socializar resultados de investigación que tuvieran un componente interactivo, así como una búsqueda de investigaciones que muestren la importancia del uso de lo virtual en la planificación o participación ciudadana.

Es así como llegamos Bouchar (2011), quien en su trabajo «Las promesas de la red y sus implicaciones», reflexiona acerca de lo que la red (web 2.0) promete en términos de producción y acceso al conocimiento, desde el punto de vista de las sociedades contemporáneas.

Bouchar parte de la tesis que indica que la epistemología del conocer sigue siendo la misma: incertidumbre y dinamismo, y que lo que ha cambiado es que el entorno digital ha permitido que los seres humanos apropien más fácilmente dicha epistemología. En este orden de ideas, Bouchar discute acerca de la "naturaleza" del conocimiento, las redes 
sociales y el aprendizaje, con el objetivo de cruzarlos con las dinámicas que trae consigo el contexto de la red. En este sentido, el autor reconoce nuevas posibilidades, tales como el trabajo colaborativo, la conexión muchos-muchos o la posibilidad de ser productores y consumidores al mismo tiempo; de hecho, hace hincapié en la importancia de que este nuevo entorno puede conducirnos a nuevas formas de control monopólico, en este caso, del conocimiento, lo cual podría traer como consecuencia ya no que un monopolio produzca para que muchos consumamos, sino que muchos produzcamos para que un monopolio nos venda lo que muchos producimos.

Por otro lado, Montoya, Vásquez y Salinas (2013), en su trabajo «Sistemas intertextuales transmedia: exploraciones conceptuales y aproximaciones investigativas», abordan las narrativas transmedia, en términos de las posiciones teóricas existentes, especialmente, los conceptos de expresión narrativa y relaciones intertextuales. Los autores abordan en su trabajo los siguientes temas: a) las diversas formas narrativas y textuales; b) las diferentes tecnologías de registro de la memoria, y c) las nuevas maneras de participar en la construcción de historias colectivas. Asimismo, se proponen trascender el concepto de narrativas transmedia, y sugieren suscribir la noción de "sistemas intertextuales transmedia" planteada por Kinder (1991), pues el concepto articula las narrativas y las tecnologías de registro y producción, así como las diversas formas de participar en la producción de historias.

Montoya et al. también proponen que es importante ubicar los desplazamientos teóricos y las transformaciones del transmedia, con el propósito de hacer distinciones sobre las perspectivas metodológicas, para abordar éste, desde el punto de vista investigativo. Los autores sugieren además que el abordaje del fenómeno demanda perspectivas transdisciplinares que conecten las dimensiones semióticonarrativas con las estéticas, antropológicas e industriales.

Por su parte, Grijalba y Toledano (2014), en su artículo «Nebrija MediaLab: un valor añadido a la docencia y al desarrollo de competencias», abordan la importancia de los MediaLab en el contexto de las transformaciones culturales y comunicacionales contemporáneas. Los autores sugieren que el uso de este tipo de escenarios en los procesos de enseñanza-aprendizaje posibilita entender que la educación trasciende el aula de clase tradicional, al tiempo que permite que los estudiantes de pregrado experimenten sobre escenarios reales de su ejercicio profesional. Finalmente, concluyen que este tipo de laboratorios permiten la apropiación de la filosofía de "aprender haciendo", gracias a que facilitan el desarrollo de competencias importantes para el ejercicio profesional y posibilitan que los estudiantes demuestren lo que han aprendido a través de prácticas diferentes a las de la evaluación tradicional.

Producto de la revisión de los artículos reseñados, se infiere que las investigaciones asociadas con los MediaLab tienen como rasgos comunes los siguientes aspectos: a) abordan como fenómeno la relación que establecen los usuarios con medios de comunicación, en el contexto web 2.0 ; b) reconocen la preeminencia de la inteligencia colectiva, en cuanto categoría que permite comprender las prácticas comunicativas contemporáneas, y c) actualizan la trascendencia que hoy en día tiene la participación de los usuarios, no solo en la recepción de contenidos, sino también, en su producción. Estos tres aspectos nos sirvieron para pensar la multiplataforma digital. 
Ahora bien, como ya se dijo, los MediaLab se constituyen en escenarios que propician no solo la formación, sino también, la realización de ejercicios investigativos, generalmente asociados a las prácticas comunicativas en el mundo contemporáneo y a los procesos de formación ciudadana. En este sentido, se considera importante dar cuenta de algunos de los MediaLab más reconocidos, tanto en el mundo como en Colombia, con el propósito de ampliar el contexto de referencia que sirve como base para nuestra propuesta.

El primer caso es el MediaLab del Instituto Tecnológico de Massachusetts (MIT, por sus siglas en inglés). Este laboratorio comprende un programa de formación posgradual (maestría y doctorado) y un programa de investigación. Esta experiencia constituye un ejemplo de la integración entre el sector privado - fundamentalmente industrias - y la educación superior, toda vez que allí participan empresas relacionadas con la electrónica, el entretenimiento, la moda, la atención médica, entre otras. La relación de reciprocidad que se establece entre el laboratorio y el sector privado se fundamenta en el intercambio de capacidades instaladas, tanto desde el punto de vista económico como desde el punto de vista científico y tecnológico.

El MediaLab del MIT tiene como fundamento el uso de las tecnologías digitales, lo cual implica que la mayoría de sus investigaciones constituyen experimentos que se llevan a cabo en el mismo laboratorio. La metodología de investigación se centra en el trabajo colaborativo, la inteligencia colectiva y la perspectiva transdisciplinar, y sus principales temas de investigación están asociados con biotecnología, mecatrónica, neurobiología y medicina.

Otro MediaLab es el Prado de Madrid (España), el cual se constituye en un laboratorio de participación ciudadana, que gira en torno a procesos relacionados con proyectos culturales, en el contexto de las redes digitales. Sus actividades se centran en la producción, difusión e investigación de experiencias culturares ocurridas en contextos web.

El MediaLab-Prado tiene dos objetivos fundamentales. El primero es habilitar una plataforma abierta, que invite a los usuarios a configurar, alterar y modificar los procesos de investigación y producción; en tanto que el segundo es sostener una comunidad activa de usuarios a través del desarrollo de procesos colaborativos. Como se observa, al igual que el laboratorio del MIT, el MediaLab-Prado tienen como fundamento la investigación y la formación en contextos colaborativos y de inteligencia colectiva, con la diferencia de que el segundo se centra exclusivamente en procesos culturales y ciudadanos.

En Colombia se han desarrollado experiencias inspiradas en la lógica de trabajo de los dos laboratorios descritos. Uno de ellos es el MediaLab EAFIT9 (Medellín), que según sus creadores, se constituye en:

(...) un espacio desde la comunicación social en el que se abren espacios para el aprendizaje y la investigación de la cultura digital y los cibermedios. Se constituye en un escenario para la experimentación y la producción de contenidos digitales en contextos comunicativos emergentes (párr. 4).

9. Vínculo al MediaLab EAFIT: http://www.eafit.edu.co/medialab/Paginas/inicio.aspx 
El MediaLab de EAFIT es un laboratorio centrado exclusivamente en lo comunicativo, por lo que sus líneas de acción son las siguientes: a) hipermediaciones; b) cultura hipermedia; c) embriónica; d) LivingLabs, y e) cibermedios. En el contexto de estas líneas, el laboratorio realiza actividades que comprenden tanto la investigación como la educación formal, no formal e informal. Dentro de las experiencias más destacadas se encuentran la Maestría en Narrativas Transmedia (formal) y los diferentes talleres en interfaz, composición, etc. (no formal).

En síntesis, se puede afirmar que los MediaLab, en cuanto espacios colectivos, se caracterizan por desarrollar procesos de investigación, extensión y educación, mediados por la cibercultura y el ciberespacio. Por tanto, sus lógicas de funcionamiento se fundamentan en la experimentación, la interactividad, el trabajo colaborativo, la transdisciplinariedad y la inteligencia colectiva. Es importante aclarar que los MediaLab no son un proyecto particular, sino que se constituyen en escenarios que sirven como soporte y fuente de inspiración para la realización de proyectos de diversa índole en el contexto de la sociedad contemporánea.

La revisión de trabajos de investigación y de procesos relacionados con los MediaLab permitió que se identificara otro tipo de procesos que se desarrollan en el contexto de la cultura digital, que tienen relación directa con los MediaLab: los LivingLab.

Con origen en el MediaLab del MIT, los LivingLab son básicamente laboratorios de trabajo. Roldan (2011) define los LivingLab de la siguiente forma:

Un Living Lab o "Laboratorio Viviente" (muy diferente de un Vive Lab), es un nuevo modelo en el que todos los actores (Estado, sector productivo, academia, sociedad civil organizada y los ciudadanos como la razón de ser de los anteriores), participan activamente apropiando la innovación (abierta y colaborativa), en la co-creación y validación de las soluciones que necesitan ellos mismos, en contextos de uso reales, utilizando las tecnologías de la información y la comunicación -TIC-como medio, conformando así un ecosistema de investigación y desarrollo que posibilita de manera permanente la innovación social (párr. 1).

En este orden de ideas, los LivingLab, a diferencia de los MediaLab, no involucran solo a usuarios específicos, sino también al público en general que tenga la intención de compenetrarse con los procesos desarrollados en este contexto. Si bien desarrollan procesos asociados a la investigación, esta no necesariamente se encuentra articulada de manera formal a las instituciones de educación superior, como sí sucede con los MediaLab. Por tanto, se constituyen en espacios que más allá de replicar situaciones en el laboratorio para construir conocimiento sobre ellas, hacen de la vida cotidiana un laboratorio que posibilita la indagación. En este sentido, trascienden la escisión entre laboratorio y escenario "real".

Los LivingLab comparten con los MediaLab aspectos relacionados con la cultura digital contemporánea, como son las nuevas prácticas comunicativas, los procesos de trabajo colaborativo, la inteligencia colectiva, la experimentación y la relación entre consumo y producción. Según Roldán (2011), las siguientes son las principales actividades de un LivingLab: 
- Cocreación: consiste en la relación que se establece entre consumidores y productores para el diseño y producción de contenidos.

- Exploración: está relacionada con la indagación acerca de nuevos usos, comportamientos sociales y nuevas oportunidades en el mercado. Esto es lo que se denomina procesos de vigilancia tecnológica.

- Experimentación: consiste en la implementación de los escenarios en vivo en el contexto de las comunidades de usuarios. Aquí se trasciende la separación entre laboratorio y mundo "real".

- Evaluación: consiste en la ponderación de los procesos realizados tomando como criterios lo socio-ergonómico, lo socio-cognitivo y lo socioeconómico.

Lo anterior permite inferir que la propuesta de los LivingLab se caracteriza por constituir proyectos de investigación concretos, que se encuentran articulados a líneas de acción generales, que inspiran las dinámicas inherentes a los MediaLab.

Si bien no surgen en el contexto de los MediaLab ni de los LivingLab, es importante hacer referencia a los ViveLab, por cuanto comparten una característica central los anteriores: la relación de las TIC con los diferentes sectores sociales. En tal sentido, los ViveLab no se caracterizan por ser laboratorios que propicien la educación y la creación de conocimiento en contextos digitales, sino por ser el escenario que proyecta la posibilidad de mejorar los niveles de inclusión y apropiación de las TIC en el conjunto global de la sociedad, por tanto, se acerca a la idea de política pública.

Para el caso de Colombia, la política gubernamental Vive Digital busca, a través de un plan a cuatro años, que Colombia concrete un avance significativo en materia de tecnología a través de la masificación del Internet y el desarrollo del ecosistema digital nacional. De allí que la política tenga como fundamento ampliar la infraestructura tecnológica de Colombia, para que sea apropiada por la ciudadanía.

Es probable que surja la pregunta acerca de la relación de los ViveLab con los MediaLab y los LivingLab, frente a la cual se puede responder que los primeros se constituyen en el fundamento de los otros dos. En consecuencia, su implementación exige la formación de los ciudadanos digitales, que son finalmente quienes constituyen la base del funcionamiento tanto de los LivingLab como de los MediaLab. No obstante, resulta lícito plantear que la labor que realizan estos dos últimos constituye un proceso de formación en ciudadanía digital, lo cual permite plantear que la relación entre estos tres escenarios es de carácter recursivo, aclarando que los LivingLab y MediaLab son especializados, mientras que la perspectiva del ViveLab es global. Una esquematización de la relación entre los tres ambientes es la siguiente: 
Figura 2. Esquema de las estructura de los LivingLab y MediaLab y ViveLab.

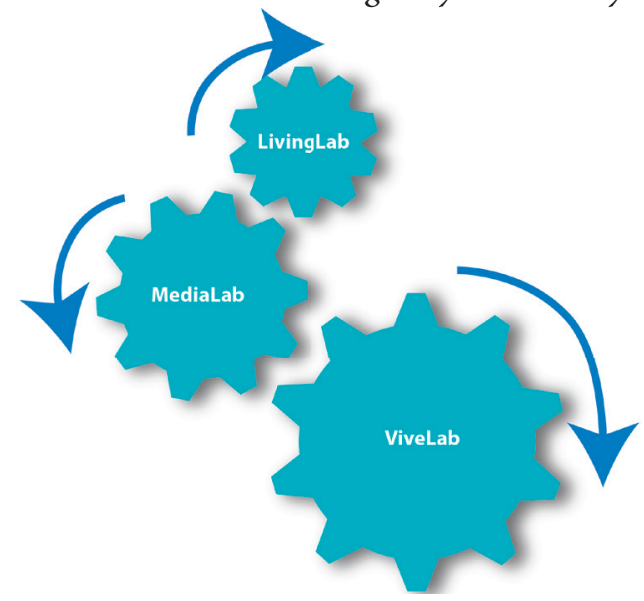

Fuente: Miguel A. Puentes

Asimismo, también hemos encontrado que hoy en día se le otorga mucha importancia al uso de la tecnología y los dispositivos móviles en la participación ciudadana; igualmente, se hace énfasis en estudios sobre lo afectivo y la significación de los lugares, para hacer planificaciones urbanas. De hecho, hasta en los diseños modernos para la planificación urbana se reconoce la calidad de la participación y retroalimentación ciudadana. Es el caso, por ejemplo, de las estrategias de ciudades inteligentes, en donde se integran los pensamientos y deseos de los ciudadanos, en una propuesta denominada Citizen Desing Science, la cual consiste en combinar las opiniones y aportes de los ciudadanos a través de tecnologías con herramientas de diseño activas (Mueller, et., 2018).

De otro lado, tal como lo plantea Savić (2017), la noción de mapeo cultural viene siendo utilizada como estrategia para entender el "sentido del lugar", noción de la que se vale la autora para adelantar su intervención en Porto; asimismo, también señala que la historia y significado de un lugar las dan la perspectiva ciudadana.

En este mismo sentido, Khettab y Chabbi-Chemrouk (2017), en su estudio sobre la ciudad costera de Tipaza (Argelia), documentan que este lugar lo delimitan el mar Mediterráneo y la montaña Chenoua, condición que influye en las imágenes mentales de las personas y en los vínculos con la ciudad. Los autores apelan al "sentido del lugar", como concepto que da cuenta de una multidimensionalidad que incorpora elementos cognitivos, motivacionales y afectivos, para determinar una territorialidad; además, también ponderan estos aspectos en la planificación urbana (paisaje urbano), configurando un escenario de planeación que trasciende los estándares de la misma Unesco.

A su turno, De Benedetto, Bellavista y Foschini (2017) proponen mejorar el uso del paradigma Mobile Crowd Sensing (MCS), que consiste en utilizar la gran cantidad de datos que los ciudadanos generan mientras recorren la ciudad, los cuales 
pueden almacenarse en los teléfonos inteligentes. Más allá de hablar de lo concreto de esa propuesta, la idea que nos interesa es la forma como los recorridos ciudadanos se involucran cada vez más en el conocimiento de la ciudad, mostrando una ciudad desde y para ellos mismos, mas no desde una visión generalizada y homogénea. Este cambio de perspectiva tendrá importantes implicaciones en las planificaciones urbanas del futuro.

A su vez, preocupados por la participación de los ciudadanos en los proyectos de desarrollo urbano, Stelzle y Rainer-Noennig (2017) proponen una base de datos de gran alcance, que recoja los enfoques (digitales o no) sobre la participación pública. Para ello, analizaron las pautas de participación en 30 municipios alemanes y catalogaron las herramientas usadas en dicha participación. Sobre la participación ciudadana, dicen los autores que «es un componente clave para una herramienta de diseño de procesos que permite a los planificadores, autoridades y gerentes diseñar diseños participativos que se correspondan estrechamente con contextos específicos» (p. 23).

Llegados a este punto, lo que queremos destacar es la preocupación por la relación ciudadanía-planificadores urbanos, en cuanto vínculo que conduce a considerar a la ciudad desde un lugar diferente al tradicional, es decir, es una postura que supera el hecho de entender a la ciudad solo como infraestructura y equipamientos homogéneos, para entenderla ahora como un espacio de imaginarios colectivos.

Ahora bien, el proyecto «Pereira Imaginada: por los croquis digitales de los ciudadanos», se relaciona más con los LivingLab que con los MediaLab en la medida que se piensa algo para el público en general, que es quien finalmente no solo se apropiará de un contenido digital, sino que también tendrá la posibilidad de modificarlo y de proponer nuevas formas o rutas para conocer su historia local y sus vivencias colectivas. En todo caso, el producto se distingue por la incorporación de la base de datos que añadimos a la plataforma, la cual recoge y sistematiza todos los recorridos ciudadanos, lo que sirve de insumo para continuar analizando la ciudad y los urbanismos ciudadanos, de forma actualizada y permanentemente.

\subsection{Metodología de construcción de la multiplataforma virtual}

Dos procesos se distinguen en la metodología de construcción de la multiplataforma virtual: 1) diseño e implementación; 2) puesta en escena de la estrategia comunicativa y análisis de los datos obtenidos en este primer ejercicio. Los contenidos son el resultado de las investigaciones realizadas sobre los imaginarios urbanos de Pereira entre 2009 y 2017. 


\subsubsection{Fase 1: uso de la información de Pereira imaginada y su actualización}

Construir la plataforma virtual exigió organizar los resultados arrojados por las investigaciones sobre los imaginarios urbanos de Pereira entre 2009 y 2017. Para ello, se tomaron las categorías de los imaginarios urbanos propuestos por Silva: ciudad (cualidades, calificaciones, escenarios); ciudadanos (temporalidades, marcas y rutinas), y otredades (afinidad, lejanía y anhelos).

A causa de la gran cantidad de datos con que se contaba, categorizar la información demandó desarrollar una estructura manual. A partir de allí se identificó cada escenario con un color, codificación que facilitó relacionarlo con el formulario base, el cual es el instrumento fundamental de recolección de información en la investigación que recoge el libro Pereira Imaginada. Con este trabajo artesanal se logró un panorama global del proyecto. Se presenta a continuación un resumen de los datos que se consideraron para la construcción de la plataforma:

\section{Imaginarios y emblemas}

De acuerdo con la teoría de Silva, los imaginarios son concentraciones simbólicas que aparecen en más del $10 \%$ de las evocaciones de la muestra seleccionada. Para el caso que nos ocupa, la muestra la conforman 250 personas, habitantes de Pereira (100\%), de una población aproximada de 500 000. Para los años que nos interesan, agrupamos los resultados de la siguiente manera:

\section{Imaginarios con baja concentración simbólica}

Los imaginarios considerados en este rango tienen la particularidad de mostrar una temporalidad que va desde un presente-pasado a un presente-futuro. Así, mientras unos van pasando en la memoria, otros van emergiendo como sustitutos. Esta afirmación encuentra sustento en la diferencia que se advierte entre el tiempo cronológico de existencia en la vida de la ciudad y la percepción sus ciudadanos (imaginarios de ciudad).

\section{Área ciudad: cualidades, calificaciones y escenarios}

En la metodología de los imaginarios urbanos de Silva encontramos las tres áreas centrales para capturar los imaginarios: ciudad, ciudadanos y otredades. En este aparte se da cuenta del área de ciudad y sus subcategorías (cualidades, calificaciones y escenarios), las cuales muestran los sentimientos que los ciudadanos expresan sobre la ciudad física. 


\section{Cualidades}

Producto del proyecto Pereira imaginada (2009), en la categoría cualidades se encontraba lo siguiente: que el Lago Uribe Uribe aún se evocaba como un lugar para relajarse, para vivir los recuerdos y por bonito; que el Zoológico Matecaña también se reconocía como un espacio que identificaba a la ciudad; que Ciudad Victoria emergía como otro espacio destacado, y que la arquitectura de la Catedral de Nuestra Señora de la Pobreza y el Viaducto recuperaban un lugar especial.

Para los ciudadanos, las construcciones alrededor del transporte masivo (Megabús e Intercambiador de Cuba) aparecían como los acontecimientos que marcaron el año 2008. También advirtieron que durante los últimos treinta años la ciudad estuvo marcada por los terremotos (1938-1999), y que la construcción del Viaducto y la puesta en marcha del Megabús fueron hitos importantes.

Finalmente, el amarillo fue el color que se erigió como emblema de la ciudad, el cual se destacaba en esa franja de imaginarios. A su vez, el verde y el rojo seguían al amarillo en orden de importancia.

\section{Calificaciones}

Las calificaciones recogen las percepciones que se tiene sobre hechos, situaciones o personajes de la ciudad. Las calificaciones representan la relación de los ciudadanos con los fenómenos de la ciudad.

Es así como la educación, el empleo-trabajo, los parques, la seguridad y el desarrollo vial aparecían como necesidades básicas en la ciudad. Del mismo modo, otras calificaciones al respecto de lo que gusta de la ciudad indicaban lo siguiente: Pereira se destacaba por su ubicación geográfica como punto estratégico con respecto a ciudades como Medellín, Cali y Bogotá. También se subrayaban características como amable, tranquila, libertad, alegría, pluralidad, comodidades, acogedora, de empuje, que recibe. Finalmente, se subrayaban las cualidades físicas, como el tamaño pequeño pero que lo contiene todo y la infraestructura.

Por otro lado, los ciudadanos reconocían algunos aspectos que no les gustaban, como la inseguridad, los dirigentes políticos, la violencia, el desempleo, los vicios, y algunos aspectos del medioambiente, como las basuras, el desaseo, el desinterés de la gente por el entorno, y la contaminación atmosférica y visual.

\section{Escenarios}

Los escenarios son lugares donde los ciudadanos, o viven o se representan la ciudad. Así, además de los centros comerciales, el parque y la casa aparecían como lugares para una cita en pareja. Después de ser un emblema negativo, el Parque de la Libertad emergía como un escenario que gustaba "en algo", pero solo en este rango de percepción. A su vez, el Lago Uribe se debatía entre el gustar y no gustar en la percepción de los ciudadanos, casi en las mismas proporciones, que van entre nada-algo, bastante y 
mucho. Se podría plantear que este escenario de ciudad se resiste a desaparecer en el imaginario de ciudad en su valoración positiva, entrando en esa tensión de gustar y no gustar en similar proporción.

La Plaza de Bolívar seguía siendo reconocida por los ciudadanos como un escenario que gustaba, pero que resultaba desplazado por otros escenarios que van ocupando una mayor valoración positiva. El Parque Olaya Herrera recibía una valoración tanto positiva como negativa, pues existían aspectos que gustaban (las fuentes, los árboles, la iglesia) y otros que no, y lo llenaban de sentimientos negativos (la "inseguridad").

El Parque Comfamiliar, que pertenece a la Caja de Compensación de los Trabajadores, era considerado el lugar por excelencia del esparcimiento familiar, especialmente los fines de semana.

Después del terremoto de 1999, la plaza de mercado tradicional se trasladó a un nuevo escenario. Así, la Nueva Plaza de Mercado Impala (por la calle 40) se estableció como el sustituto de la antigua Galería, pero en el imaginario colectivo aún se notaba su ausencia.

El Centro Comercial Ciudad Victoria es el sustituto de la plaza de mercado tradicional (la antigua Galería), y es un escenario que gradualmente se fue consolidando como un lugar valorado positivamente por los ciudadanos. Del mismo modo, la Avenida Circunvalar es un escenario que toma cada vez más fuerza; mientras que Cerritos es un lugar de paseo familiar los fines de semana y, por lo tanto, valorado positivamente.

El Viaducto se veía como un símbolo de modernidad, pues con él sintieron que dejaron de ser "pueblo" para convertirse en ciudadanos del mundo. El Viaducto facilitó que pereiranos y biquebradenses se conectaran más fácilmente, en tanto que su arquitectura los hace sentir que viven en una gran metrópolis.

La Villa Olímpica es un escenario deportivo en el que se aprecia el gusto ciudadano. Por su parte, el Parque de la Vida (espacio conmemorativo, nombrado así para recordar a los niños víctimas del violador Luis Alfredo Garavito), por el contrario, resulta marcado con una valoración negativa, además, es un lugar ausente del imaginario colectivo; en tanto que el Parque la Libertad y la calle 13 son las zonas que se perciben como las más peligrosas de la ciudad.

Otros lugares que se destacaron en la percepción ciudadana son los centros comerciales, en cuanto espacios con el mejor olor. Las carreras $6^{\circ}$ y $8^{\circ}$ fueron percibidas como las más transitadas por las mujeres, mientras que la Plaza Bolívar y el Centro son los lugares percibidos como más transitados por los hombres. A su vez, Ciudad Victoria y la Circunvalar se perciben como los lugares más transitado por los jóvenes.

La característica primordial de las zonas identificadas para las mujeres es la gran cantidad de comercio que en ellas existe; mientras que las zonas identificadas para los hombres son ocupadas por los jubilados, desempleados o zonas de trabajo; en tanto que los centros comerciales son los lugares de los jóvenes.

De lo anterior se desprende que existe una percepción diferenciada en la consideración de las zonas y lugares más transitados: hay una marcada diferencia entre hombres, mujeres y jóvenes. 


\section{Área ciudadanos: temporalidades, marcas, rutinas}

El área ciudadanos comprende la relación del ciudadano con sus formas de ser urbano y con las maneras de relacionarse, representarse e imaginarse, es decir, abarca sus propias realizaciones sociales. El área presenta las subcategorías temporalidad, marcas y rutinas.

\section{Temporalidades}

La temporalidad se entiende como tiempo cronológico, mas no como tiempo de la vida. La explicación de las horas debe considerar dos factores: el primero es el tiempo que gasta la persona en ir al trabajo, volver a almorzar, regresar al trabajo y volver a la casa; el otro tiene que ver con la sensación que reporta el encuestado al tener que transportarse de un lugar a otro - esto es, la demora del traslado-, hecho que repercute en el estado de ánimo y la percepción de temporalidad humana.

El tiempo empleado en movilizarse flota en un rango de entre 1 y 4 horas, siendo entre 1 y 2 horas el rango más referido. Los resultados permiten establecer que en la ciudad predominan las distancias cortas entre los hogares y los lugares de trabajo. También se confirman dos de los aspectos que los ciudadanos destacan: su tamaño y su red vial. Se trata de dos atributos que facilitan el flujo del transporte y dan la posibilidad de ir a almorzar a la casa, aumentan el tiempo que se le puede dedicar a la familia y, en conclusión, mejoran la calidad de vida que se percibe en la ciudad.

Asimismo, las horas dedicadas al trabajo por día, con jornadas de doce horas seguidas y por más de doce horas, no muestran una alta concentración simbólica, sin embargo, emergen como imaginarios. Con base en lo anterior, se podría arriesgar una inferencia: que la categoría empleado ya no se asocia tanto con las ocho horas de trabajo, sino que se va desplazando a otra temporalidad diaria.

\section{Marcas}

Así como los ciudadanos marcan la ciudad, igualmente la ciudad los marca. Los aspectos que se destacan en esta categoría son los inventos más importantes del siglo: la Internet y el celular. El vehículo particular aparece en esta concentración como marca de movilidad ciudadana.

Dos visiones de juventud se perciben claramente entre los ciudadanos: una positiva y otra negativa. Es decir, los jóvenes son identificados con vicios y mal comportamiento, pero, al mismo tiempo, con creatividad y emprendimiento.

Las personas de la tercera edad se evocan a partir de sus roles (abuelos, pensionados); su edad (adultos mayores, ancianos); sus cualidades (bondad, conocimiento, experiencia, tranquilidad, tristeza, sabiduría, soledad); sus calificaciones (solos, bondadosos, cariñosos, desamparados, olvido, tiernos, cucho); su aspecto físico (enfermos, hipertensos), y por lo que inspiran en el otro (respeto, recuerdo). 


\section{Rutinas}

Los modos de vivir, imaginar y sentir la ciudad se evidencian en las rutinas que allí se van construyendo. Los aspectos de la percepción ciudadana que se destacan en esta categoría son la frecuencia de uso del teatro (que se ubica entre algo y un poco-de allí en adelante desaparece como imaginario de uso-) y la frecuencia de asistencia a recitales y conciertos (que se percibe entre algo y un poco).

Preocupa que la frecuencia de uso de la lectura fuera percibida como poca. En este rubro, la frecuencia de lectura del periódico es mediana, mientras que la frecuencia de lectura de revistas está dada por algo y un poco, seguidas de nada y mucho. La frecuencia de lectura de material especializado se reconoce entre algo y mucho, pero en menos proporción que nada. Y por lo que respecta a la literatura, aparece con una frecuencia entre algo y bastante, donde mucho desaparece como imaginario y la mayor frecuencia es nada.

Ahora, en lo relacionado con los espacios, se encuentra que la frecuencia de uso de los espacios deportivos es baja. Igual ocurre con la biblioteca y los espectáculos deportivos, en tanto que la frecuencia de asistencia a cine se aprecia como mediana.

Con respecto al cuidado del cuerpo, se reconoce que su importancia es baja. Pero caso distinto ocurre con la alimentación, pues el cuidado del cuerpo se incorpora como una tendencia fuerte.

Las comidas que más se consumen son la bandeja paisa, la comida casera, los fríjoles y la comida típica, seguidas por las sopas, el sancocho, el arroz y los vegetales; no obstante se va notando un cambio, por el descenso en la frecuencia de consumo de este tipo de comidas.

Comer en restaurante entre semana tiene una frecuencia baja, mientras que la casa es el lugar por excelencia. Sin embargo, esta frecuencia aumenta los fines de semana, es decir, se come más en restaurantes, aunque no se desplaza la casa.

Finalmente, otros aspectos que se destacan de la percepción ciudadana son los siguientes: los pereiranos escuchan música mientras se trasladan al lugar de trabajo; la computadora se usa para el entretenimiento, la comunicación, la información y estudiar, aunque el mayor uso se da para el trabajo; para comunicarse con la familia y los amigos, el celular ocupa el lugar privilegiado, en tanto que otros medios son: personalmente, teléfono y correo electrónico; ver televisión (actividades en la casa) y escuchar música son las dos dimensiones que más aparecen en el tiempo libre; viajar y deportes, seguido muy de cerca por pasear, son las actividades que les gustaría hacer en su tiempo libre.

\section{Otredades}

En cuanto a las otredades, esto es, las afinidades, no afinidades y el deseo frente a los otros, los ciudadanos identifican a Bogotá con frío y congestión en el transporte; a Cali la asocian con rumba y parranda, calor y salsa; a Medellín la reconocen como emprendedora, y a Armenia la relacionan con café. 


\subsubsection{Fase 2: diseño e implementación de la plataforma virtual}

La fase dos del proyecto involucró el diseño e implementación de la plataforma virtual, producto que se establece como resultado de este ejercicio investigativo.

Después de varios años de investigación, decidimos hacer un alto en el camino para pensar qué hacer con toda esta información. Esta pausa dejó que se decantaran dos preguntas: ¿cómo aportar desde la experiencia acumulada y el conocimiento a la apropiación social del conocimiento sobre la ciudad y ciudadanos de Pereira? y ¿qué camino seguir para hacer sostenible el proceso de conocimiento adquirido y las aplicaciones que se derivan del mismo?

Con el objeto de responder a esos interrogantes propusimos la segunda fase (metodología), la cual exigió la creación de la plataforma virtual para dar a conocer esta información y, al tiempo, obtener en vivo y en directo la actualización de la misma.

La mecánica del ejercicio consistió que a medida que los ciudadanos hacían el recorrido por la información, contestarían las preguntas insertas en la misma plataforma. Con esto no solo actualizaríamos la nueva información, sino, también, se validaría la anterior.

\section{Diseño de la plataforma virtual}

El diseño de la plataforma virtual se realizó en varias etapas, primero manual y luego digital, hasta darle forma a la maqueta, para que se programara y luego funcionara.

\section{Paso 1}

La información se estructuró en función de las categorías y subcategorías que propone la teoría de imaginarios urbanos desarrollada por Silva (Figura 3).

Figura 3. Fotografías de categorías y subcategorías de la teoría de imaginarios urbanos: (a) área ciudad; (b) área ciudadanos; (c) área otredades

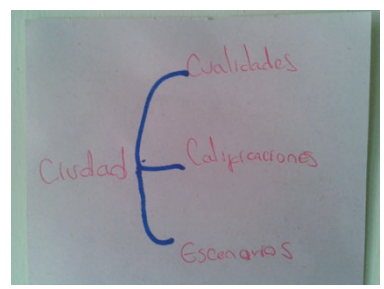

(a)

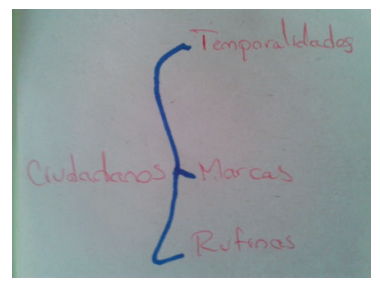

(b)

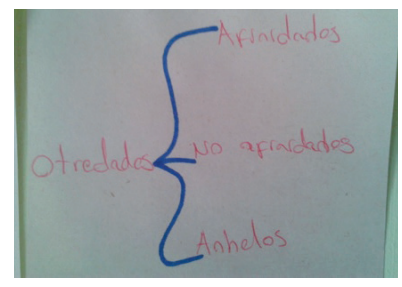

(c)

Fuente: elaboración propia a partir de la metodología de trabajo desarrollada por el proyecto Pereira Imaginada y basada en la metodología de Silva 


\section{Paso 2}

Luego de tramitar el paso 1, se procedió a llenar las categorías con la información de los resultados de investigación de Pereira Imaginada (2009). El objetivo era incluir/ eliminar información, para poder así seleccionar lo que quedaría en la plataforma.

Figura 4. Fotografías la categorización manual de la información

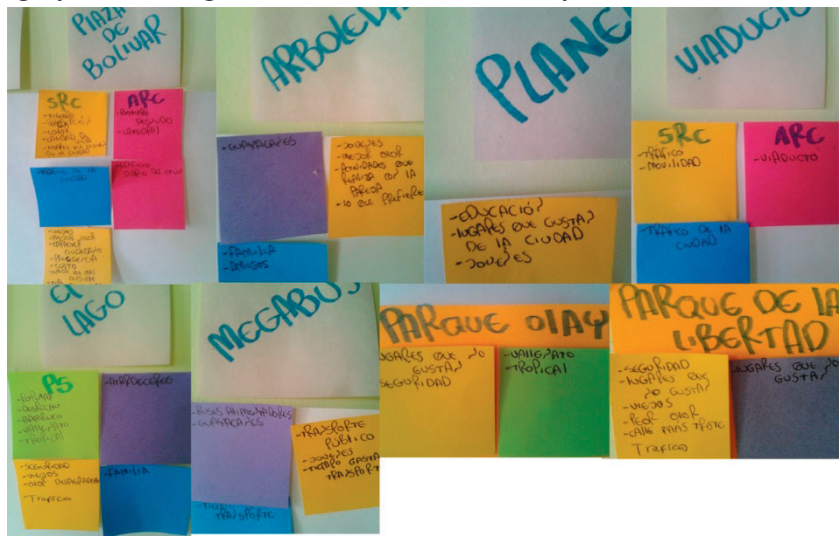

Fuente: archivo particular del proyecto de investigación (adaptado de los resultados del proyecto Pereira Imaginada, 2014)

\section{Paso 3}

Una vez terminado el proceso de depuración manual de la información, se procedió a la sistematización digital.

Figura 5. Captura de pantalla de la primera categorización digital de la información

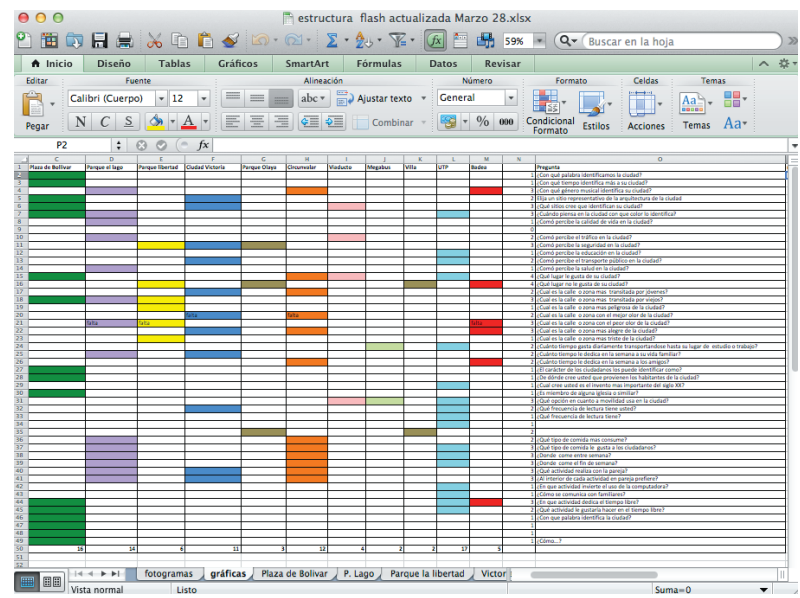

Fuente: archivo particular del proyecto de investigación (adaptado de los resultados del proyecto Pereira Imaginada, año 2014) 
En la tabla de la Figura 5 se relacionan las respuestas (a la izquierda) con las preguntas (a la derecha). Se usa el mismo color para las mismas respuestas en diferentes preguntas, toda vez que esa codificación será de gran utilidad en la programación posterior.

\section{Paso 4}

Después de identificar las respuestas con cada color y de buscar relaciones de los datos con el formulario base, se pasó a pensar sobre las herramientas adecuadas, que permitan convertir esta propuesta en un escenario de innovación, multimedial e interactivo. Para el caso, se indagó por las siguientes estrategias:

- Mapa menú: consiste en un mapa normal (captura de una imagen de la ciudad -Google Maps-), usado para recrear la ciudad de Pereira. Este elemento se usará como menú de navegación, a través de once (11) escenarios previamente seleccionados. El recurso permitirá romper con la forma tradicional de menú (que usualmente es horizontal o vertical y en letras). Cada escenario se identifica con fotos-íconos circulares.

- Paisaje Sonoro (PS): es una técnica de grabación de audios ambientados, sin ninguna edición o alteración.

- Fotografía Panorámica (FP): se trata de una técnica fotográfica que permite trabajar escenarios en $360^{\circ}$.

- Video (V): es una tecnología de grabación de imágenes en movimiento.

- Estadística (E): es una herramienta de análisis y administración de información.

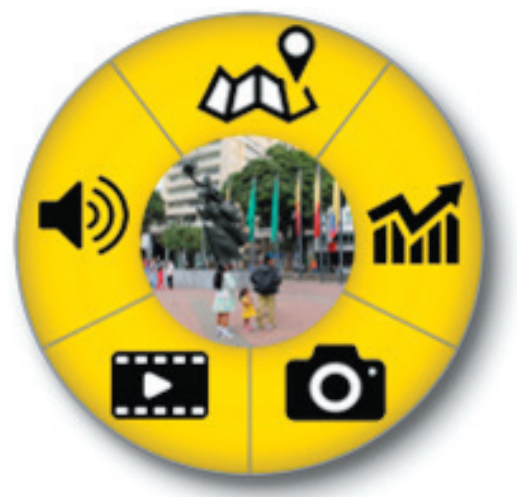

Fuente: Miguel Puentes

El pretexto para usar estas cuatro herramientas no se sustenta en su definición técnica, sino en su usabilidad, que no es otra cosa que la posibilidad de interactuar con información, entre lo real y lo virtual. Lo que se pretende es agudizar los sentidos del ciudadano, fundamentalmente la vista y el oído, posibilitando así una mayor interacción. 


\section{Paso 5}

La técnica para desarrollar cada una de las cuatro herramientas exigió el perfeccionamiento de las funciones de manejo y pensar en su posterior desarrollo; asimismo, las herramientas exigieron que el diseño soportara la estructura del material, y demandó trabajar los planos, identificar los ritmos de cada uno de los escenarios y planear la puesta en escena, para el recorrido y la obtención de más información.

Este paso requirió realizar una búsqueda en Internet de software especializado, que soportara el desarrollo de la plataforma. Como resultado, para el desarrollo de las técnicas, se usó tanto software libre como de pago. Algunos de los softwares utilizados fueron los siguientes:

- Adobe Photoshop: editor de imagen fijas, especial para hacer fotografías panorámicas.

- Adobe Flash: editor de animación en 2D y multimedia.

- Adobe Premier: editor de imagen en movimiento, especial para hacer videos.

- Adobe Audition: editor especializado de sonido.

\section{Paso 6}

Dependiendo del valor y utilidad de los datos, en este paso se buscó acomodarlos a cada una de las herramientas por utilizar. Pensar en cómo definir cada una de las categorías y subcategorías propuestas por Silva (para mirar el cómo y definirlas bajo códigos de color), posibilitó organizar de mejor forma cada una de las informaciones y tener mayor control sobre los resultados. 
Tabla 2. Categorización primaria de la información

\begin{tabular}{|c|c|c|c|}
\hline Estructura & $\begin{array}{l}\text { etodológica para ciudades } \\
\text { imaginadas }\end{array}$ & $\begin{array}{l}\text { ¿Qué? Títulos de las gráficas de los } \\
\text { resultados de la investigación Pereira } \\
\text { imaginada 2009-2014 }\end{array}$ & $\begin{array}{l}\text { ¿Cómo? Medios para } \\
\text { diseñar contenidos }\end{array}$ \\
\hline \multirow[b]{3}{*}{ Área ciudad } & Cualidades urbanas & $\begin{array}{l}\text { 1. Tipo de música con que los ciudadanos } \\
\text { identifican la ciudad } \\
\text { 2. Arquitectura representativa de la ciudad } \\
\text { 3. Tres sitios representativos de la ciudad } \\
\text { 4. Color con que los ciudadanos identifican } \\
\text { la ciudad } \\
\text { 5. Tiempo con que identifica la ciudad }\end{array}$ & \multirow{9}{*}{ 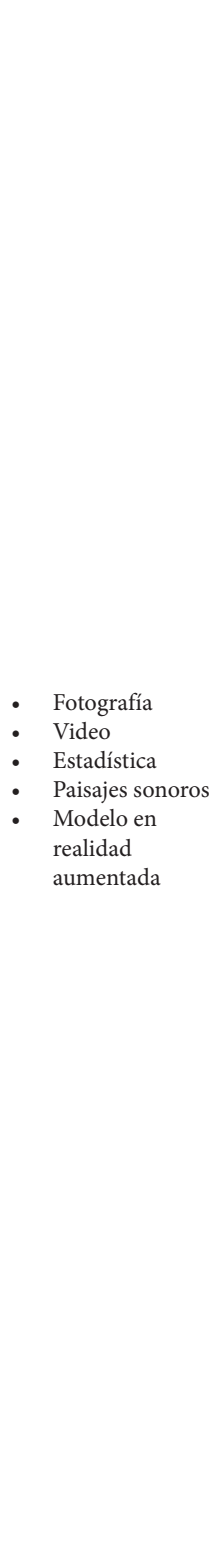 } \\
\hline & Calificaciones urbanas & $\begin{array}{l}\text { 1. Tráfico de la ciudad } \\
\text { 2. Salud } \\
\text { 3. Educación }\end{array}$ & \\
\hline & Escenarios urbanos & $\begin{array}{l}\text { 1. Lugares que más gustan } \\
\text { 2. Lugares que menos gustan } \\
\text { 3. Calle o zona más transitada por jóvenes } \\
\text { 4. Calle o zona más transitada por viejos } \\
\text { 5. Calle o zona con el mejor olor } \\
\text { 6. Calle o zona con el peor olor } \\
\text { 7. Calle o zona más alegre } \\
\text { 8. Calle o zona más triste } \\
\text { 9. Calle o zona más peligrosa }\end{array}$ & \\
\hline \multirow{3}{*}{$\begin{array}{c}\text { Área } \\
\text { ciudadanos }\end{array}$} & Temporalidades ciudadanas & $\begin{array}{l}\text { 1. Tiempo que gastan transportándose } \\
\text { diariamente al estudio o trabajo } \\
\text { 2. Tiempo en horas dedicado a la vida } \\
\text { familiar } \\
\text { 3. Tiempo en horas dedicado a los amigos }\end{array}$ & \\
\hline & Marcas ciudadanas & $\begin{array}{l}\text { 1. Percepción de procedencia de los } \\
\text { habitantes de la ciudad } \\
\text { 2. ¿Es miembro de algún culto, iglesia o } \\
\text { similares? } \\
\text { 3. Invento más importante en el siglo XX } \\
\text { 4. Movilidad opción } 1\end{array}$ & \\
\hline & Rutinas ciudadanas & $\begin{array}{l}\text { 5. Rutinas en el cuidado de cuerpo } \\
\text { 6. Comida que más consume } \\
\text { 7. Tipo de comida que más le gusta a los } \\
\text { ciudadanos } \\
\text { 8. ¿Dónde come entre semana? } \\
\text { 9. ¿Dónde come el fin de semana? } \\
\text { 10. Actividades que realiza frecuentemente } \\
\text { con la pareja }\end{array}$ & \\
\hline \multirow{3}{*}{$\begin{array}{c}\text { Área } \\
\text { otredades }\end{array}$} & Ciudades afines & & \\
\hline & Ciudades no afines & & \\
\hline & Ciudades anheladas & & \\
\hline
\end{tabular}

Fuente: elaboración propia a partir del proyecto Pereira Imaginada (2014) 


\section{Paso 7}

En esta fase se creó la maqueta funcional de la interfaz digital, se desarrollaron los bocetos e ideas visuales de la plataforma multimedia y se definió la forma de levantar la información de cada uno de los escenarios para la constitución de los grupos de apoyo.

En esta fase, denominada diseño de la propuesta, maquetación y recursos, se organizó toda la propuesta visual de la plataforma: la identidad visual, los tamaños, los colores, la tipografía y la distribución espacial, al tiempo que se diseñó la página principal de la plataforma (Figura 6a). La presentación de la página inicia con una reproducción (voz en off), que induce el uso de la plataforma.

Figura 6. Fotografías del proceso de diseño de la propuesta visual: (a) maquetación de la página principal; (b) maquetación de la pantalla escenarios; (c) maquetación del menú

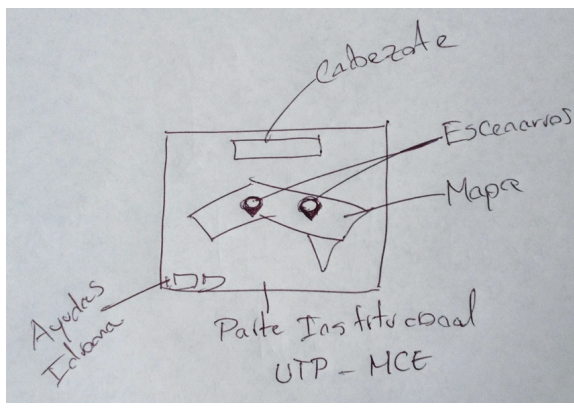

(a)

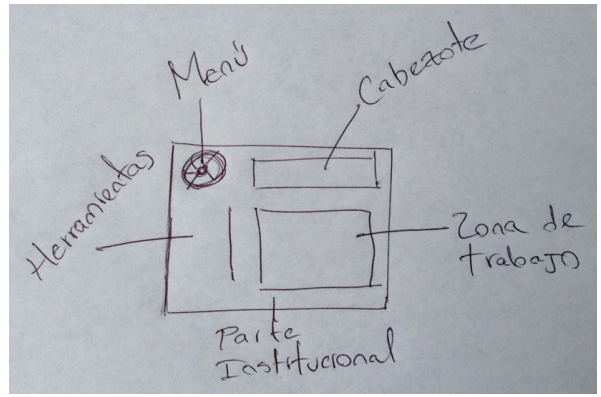

(b)

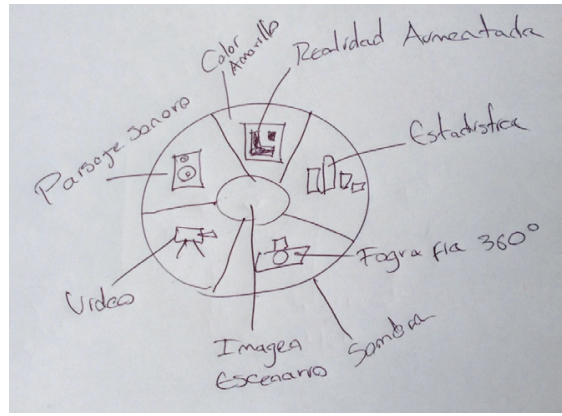

(c)

Fuente: archivo particular del proyecto de investigación

El uso de la imagen como fuente primaria, el uso de un mapa como escenario de la ciudad, y la representación icónica de cada escenario (Figura 6b) permitieron entender la lógica de navegación por la plataforma de manera intuitiva. De igual forma, los usuarios encontrarán todas las ayudas necesarias para hallar la manera de usar la estrategia, los modos de uso, la navegación y el cierre, así como los créditos y la descripción técnica del producto. 
Tras superar la página principal, el usuario (ciudadano) selecciona la información. Esta acción lo lleva a nueva pantalla, llamada escenario, donde encontrará un cabezote, que es parte de la identidad de la plataforma multimedia. Se trata de un menú circular que presenta las cuatro herramientas: FP, PS, E, V) (Figura 6c). En esta pantalla, el usuario también se encontrará con una zona de herramientas y una zona de trabajo, que cambian según la herramienta que él seleccione.

Con relación a la maquetación del menú (Figura 6b), para identificar cada una de sus acciones, se tomó la decisión de trabajar con cinco íconos. La imagen que va en el centro identifica cada uno de los escenarios. En esta fase también se definió el esquema de color de la plataforma: blanco como color base; rojo y amarillo para el cabezote; amarillo para el menú y negro para sus íconos.

La fuente tipográfica escogida es Verdana a 12 puntos, y colores negro y rojo (en negrilla) para los títulos.

\section{Paso 8}

En esta fase se procede a incluir el formulario base del proyecto «Ciudades Imaginadas: Pereira imaginada» en la herramienta.

La plataforma incluyó el formulario base utilizado en las investigaciones sobre las ciudades imaginadas y se conectó al multimedia para recolectar in situ los recorridos de los usuarios. Esta característica facilitó la sistematización y revisión progresiva de los datos y posibilitó hacer cortes por sectores poblacionales o temporales (histogramas y gráficas en Excel), según el lugar donde se ubique la plataforma. Asimismo, la plataforma también admitió que se agregaran nuevas respuestas, permitiendo así el ingreso de nuevos datos a través de la incorporación de la opción (¿otro?) que servirá para agregar respuestas no preestablecidas, permitiendo mayor participación ciudadana y una actualización efectiva.

La administración de la base de datos permitió construir sus propias gráficas e histogramas, de manera directa y en el menor tiempo, dejando que los ciudadanos, con sus propios aportes, pudieran cambiar lo presentado (Figura 7). 
Figura 7. Captura de pantalla de una parte de la base de datos del formulario base Ciudades Imaginadas

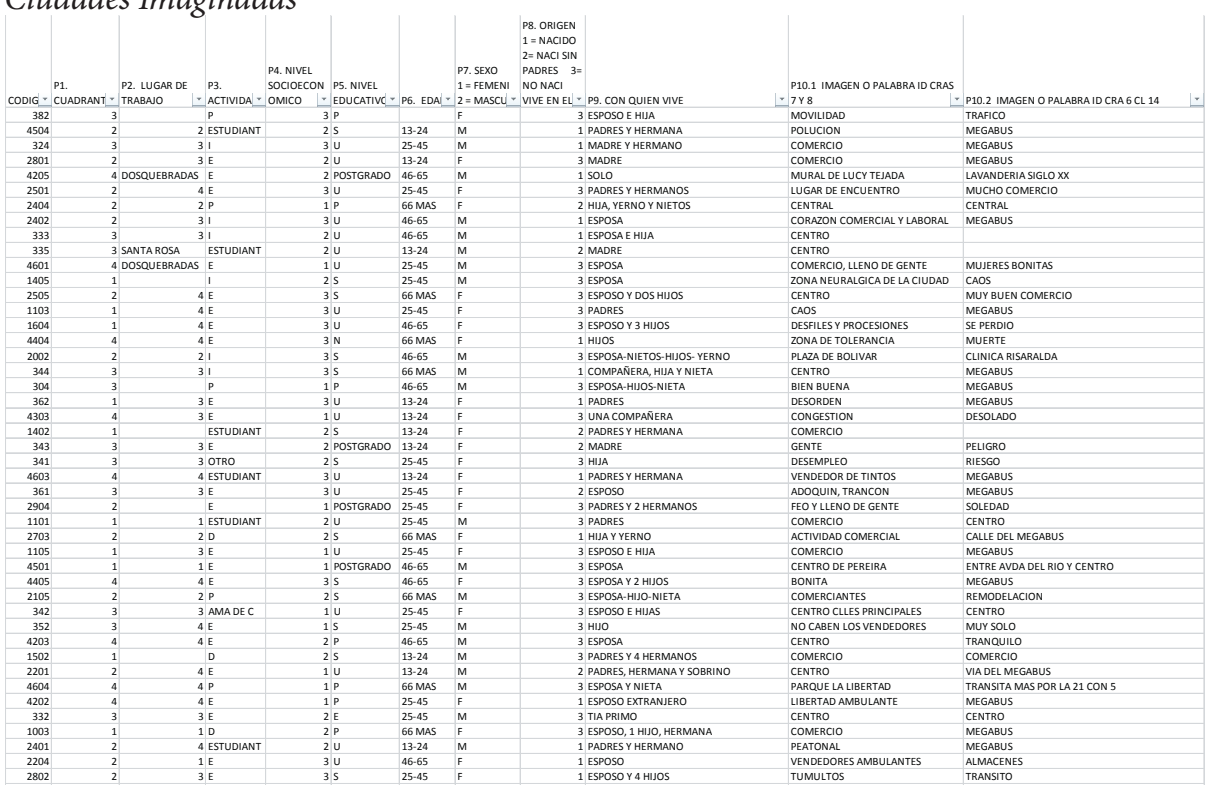

Fuente: (Silva, 2009)

\section{Paso 9}

Después de realizar toda la fase de diseño de la multiplataforma y de tener todos los borradores, se procedió a organizar toda la información por categorías y por formatos como lo definió la Tabla 2, en este sentido ya se tenían los archivos originales capturados en los diferentes formatos y definiendo su ubicación por escenarios (Figura 8) previo a la fase de montaje.

Figura 8. Captura de pantalla de la organización de la información, por escenario y por técnica

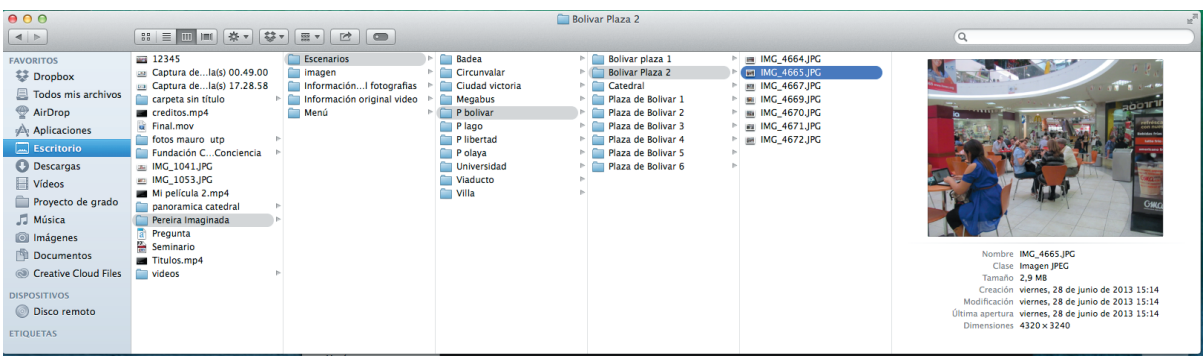

Fuente: archivo particular del proyecto de investigación 
Lo primero fue la construcción de una imagen que le diera identidad a la plataforma (Figura 9a).En este sentido se toma con símbolo el Bolívar desnudo y los colores significativos de la ciudad para establecer un ícono que sirva de referencia al proyecto. Luego, con base en un mapa general de la ciudad (tomado de Google Maps), se procedió a diseñar los 11 íconos de la página central de la multiplataforma, que presentan los 11 escenarios identificados en Pereira Imaginada (2009-2017).

Figura 9. (a) y (b): Diseño de la propuesta visual. (a) maquetación del cabezote; (b) maquetación de la página principal

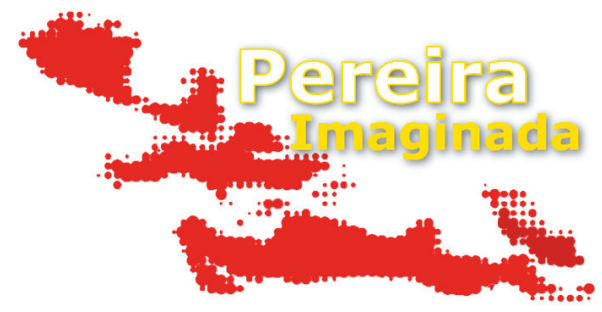

(a)

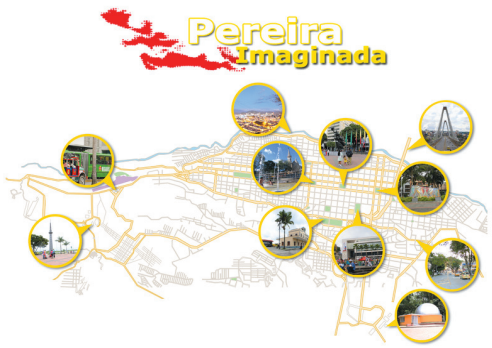

(b)

Fuente: archivo particular del proyecto de investigación

Cada escenario cuenta con una configuración propia, según el menú (Figura 10a) con las cinco herramientas planteadas para desarrollar la multiplataforma (Figura $10 \mathrm{~b})$ que permitan la navegación por los archivos de cada escenario particular.

Figura 10. Diseño de la propuesta visual: (a) maquetación de íconos del menú circular; (b) descripción del menú circular.

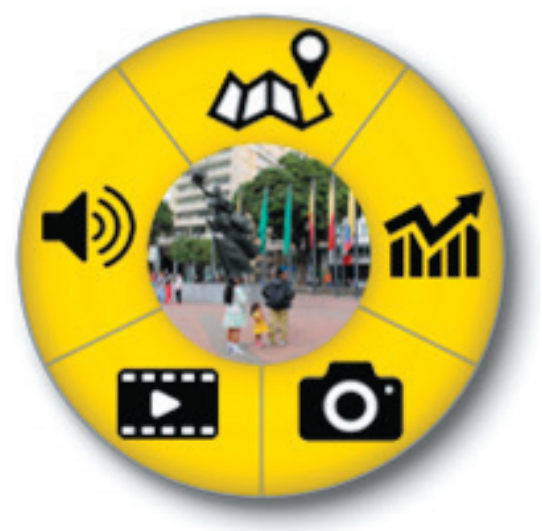

a) 


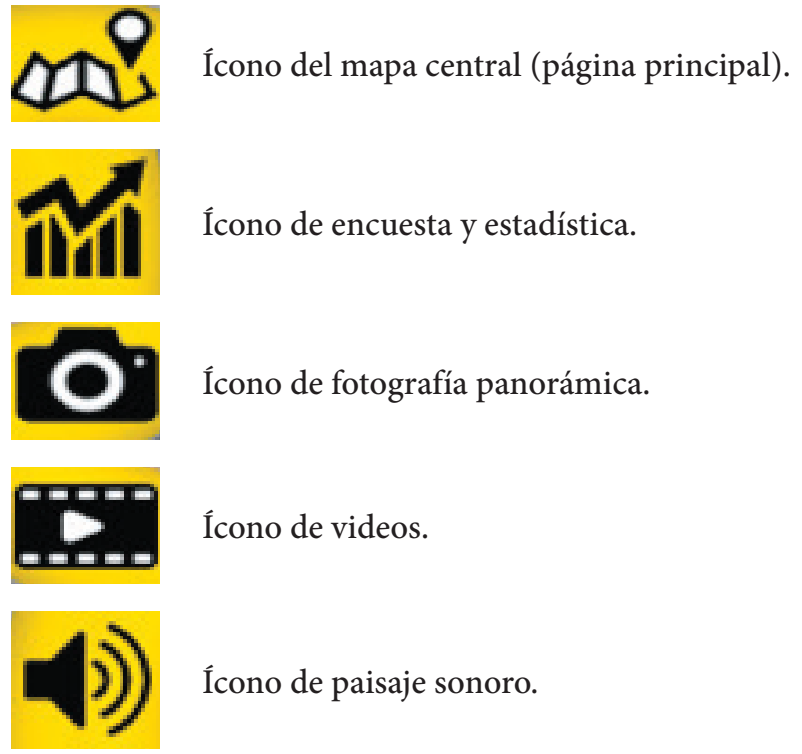

(b)

Fuente: archivo particular del proyecto de investigación

En este sentido, cada escenario tendrá una plataforma de video (Figura 11a), de paisajes sonoros (Figura 11b), así como de fotografías panorámicas.

Figura 11. Diseño de la propuesta visual: (a) maquetación de la página de videos; (b) maquetación de la página de paisajes sonoros

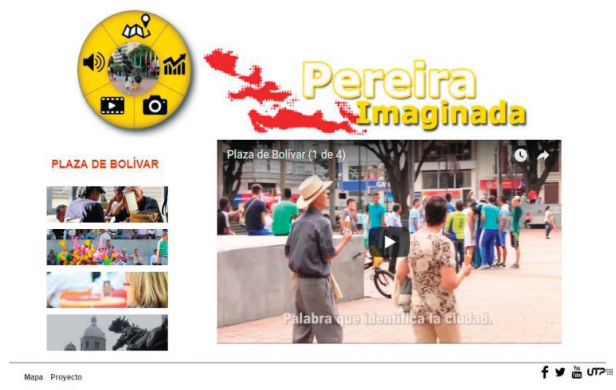

(a)

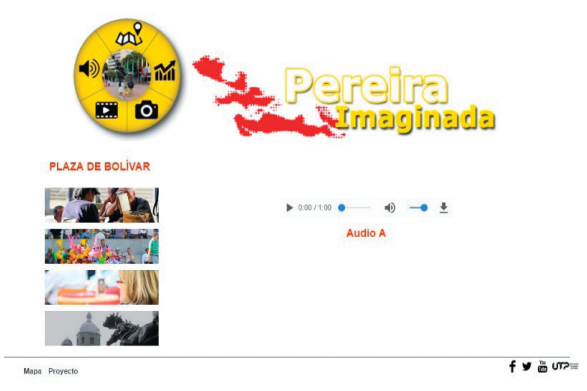

(b) 


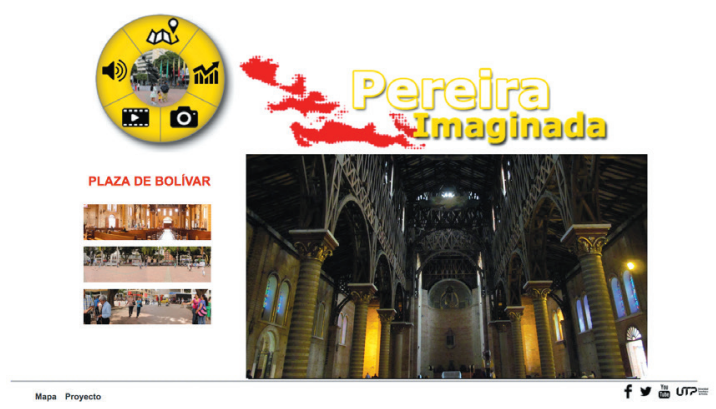

(c)

Fuente: archivo particular del proyecto de investigación

En el caso de la estadística, está conectada directamente a la base de datos, por ende al dar clic, aparecerá una sub-ventana (Figura 12a) solicitando información, la cual el usuario podrá diligenciar de manera voluntaria y aportar dichos datos al estudio, si el usuario registra los datos de género, edad, estrato social y comuna, este podrá contestar las preguntas registradas en la base de datos (Figura 12b) y que hacen parte del formulario base del proyecto; en este sentido y después de dar la respuesta, se mostrará los resultados del estudio anterior frente a dicha pregunta (Figura 12c). Cabe aclarar que las 82 preguntas están distribuidas en los 11 escenarios.

Figura 12. Diseño de la propuesta visual: (a) datos del usuario que está accediendo a la plataforma; (b) formato de pregunta y respuesta de la encuesta; (c) resultados estadísticos

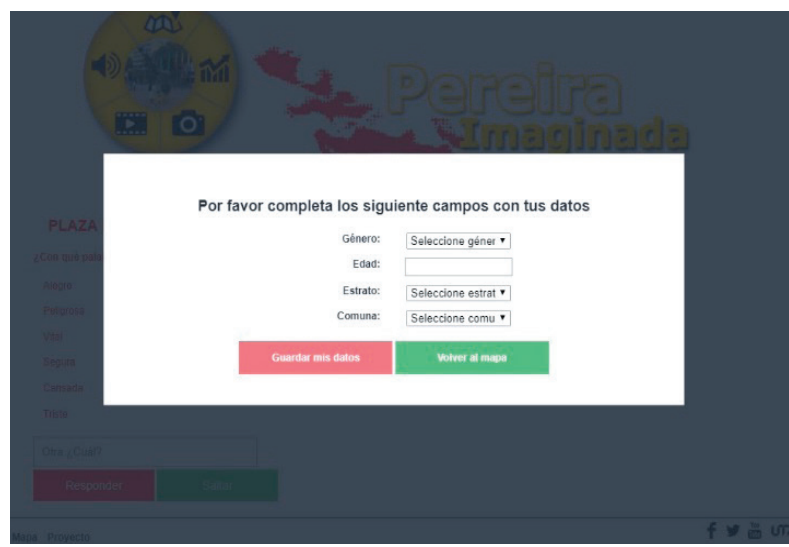

(a) 


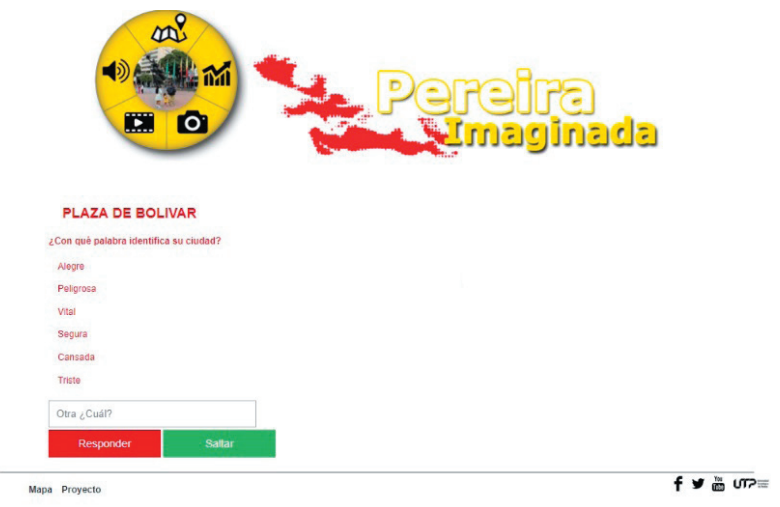

(b)
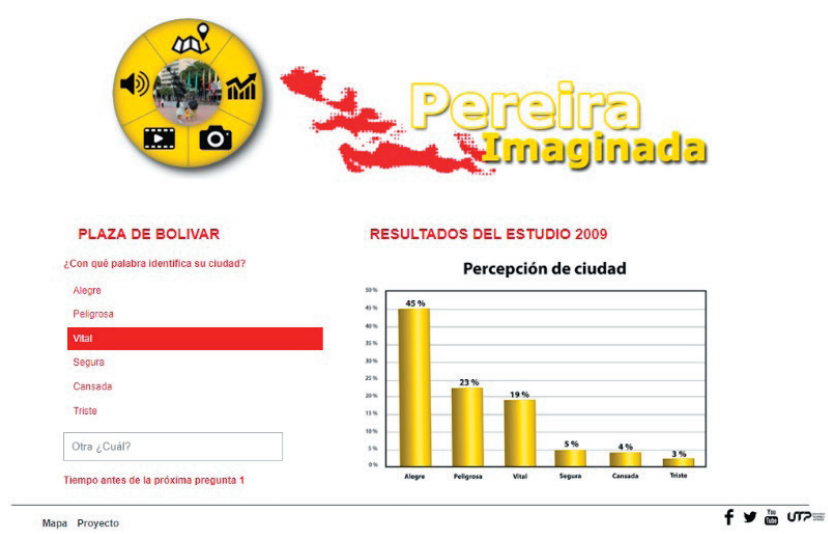

(c)

Fuente: archivo particular del proyecto de investigación

Luego de este proceso de presentar la plataforma a los ciudadanos, se presenta la parte interna que sirve como materia prima para desarrollar la investigación in situ, la plataforma cuenta con una base de datos que se alimenta continuamente a través de las respuestas ingresadas por los ciudadanos, esta permite saber a través de histogramas el número de respuestas a cualquiera de las 82 preguntas (Figura 13a), así como establecer otro tipo de reportes por género, edad, estrato social o comuna, haciendo los cruces de datos que el investigador necesite en el reporte (Figura 13b).

Figura 13. Diseño de la propuesta visual: (a) histogramas de la base de datos (b) generador de reportes de la base de datos 

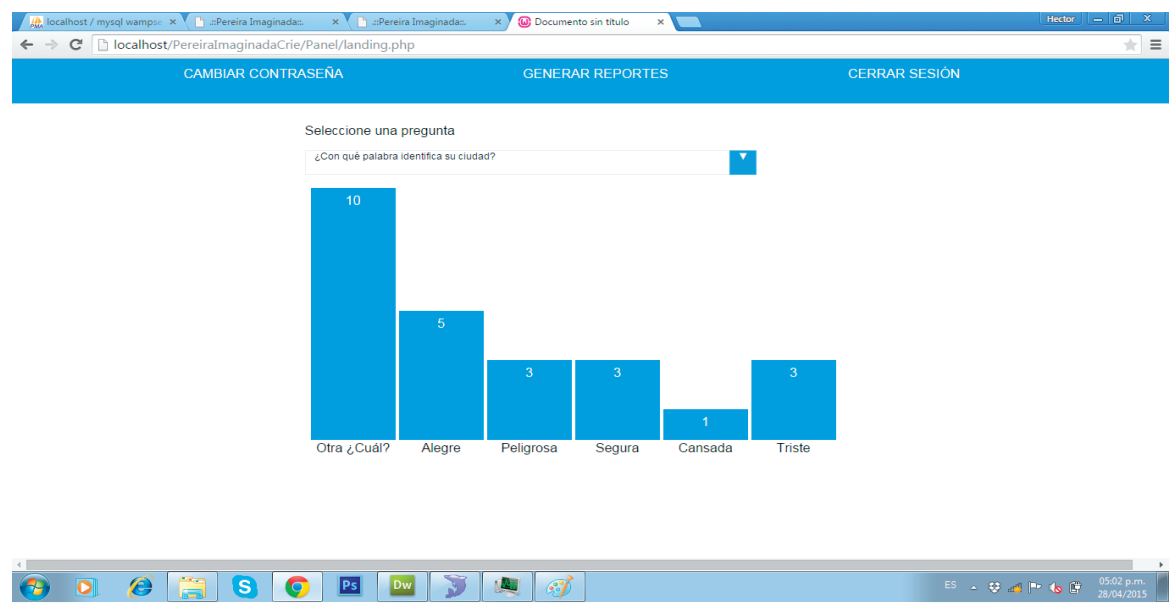

(a)

Seleccione los filtros que desee aplicar para generar el informe

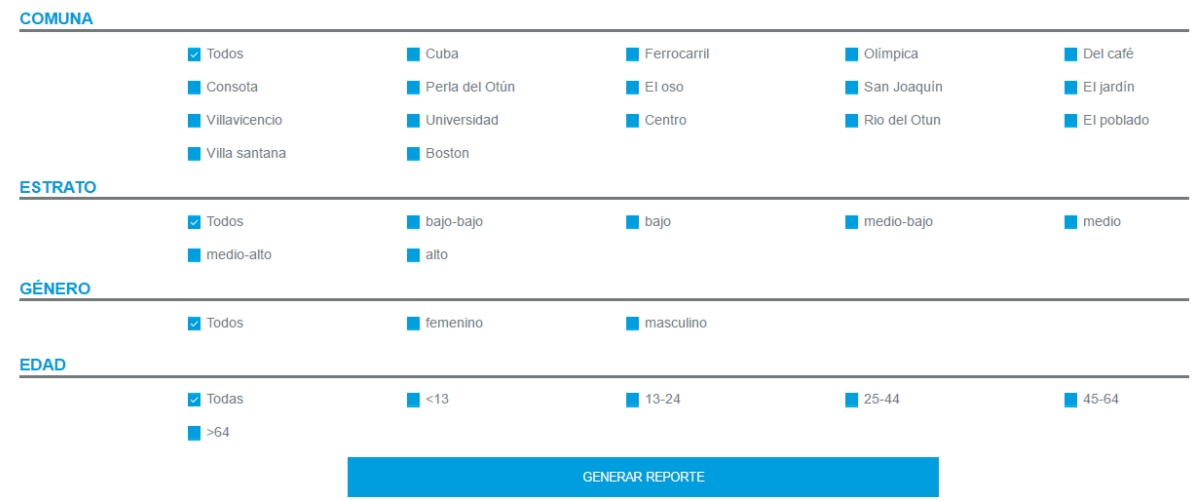

(b)

Fuente: archivo particular del proyecto de investigación

Terminada esta etapa se dio paso a la puesta en escena de la plataforma. Los objetivos de validar la herramienta y ciertos contenidos de la información de Pereira Imaginada se cumplieron, como se mostrará a continuación. En el siguiente enlace se puede consultar la multiplataforma: https://www.utp.edu.co/pereira-imaginada/\# (recuerde hacer clic en la X lado superior izquierdo, si no desea ver el video que es explicativo)

Cuando propusimos el proyecto «Por los croquis digitales: Pereira Imaginada», solo consideramos la realización de la plataforma virtual, pero no su uso ni tampoco presentar nuevos croquis de ciudad. El tiempo para desarrollar de la propuesta era corto 
al igual que los recursos. Pero al poner en funcionamiento la plataforma quedamos tan sorprendidos por la usabilidad obtenida, que decidimos no solo entregar la plataforma sino construir croquis sobre el mapa de la ciudad con los datos recolectados con ella. A partir de allí se abrió una nueva línea de trabajo: seguir explorando, al tiempo, la relación plataforma virtual/recolección y sistematización de la información.

Figura 14. (a), (b), (c) y (d). Uso de la plataforma

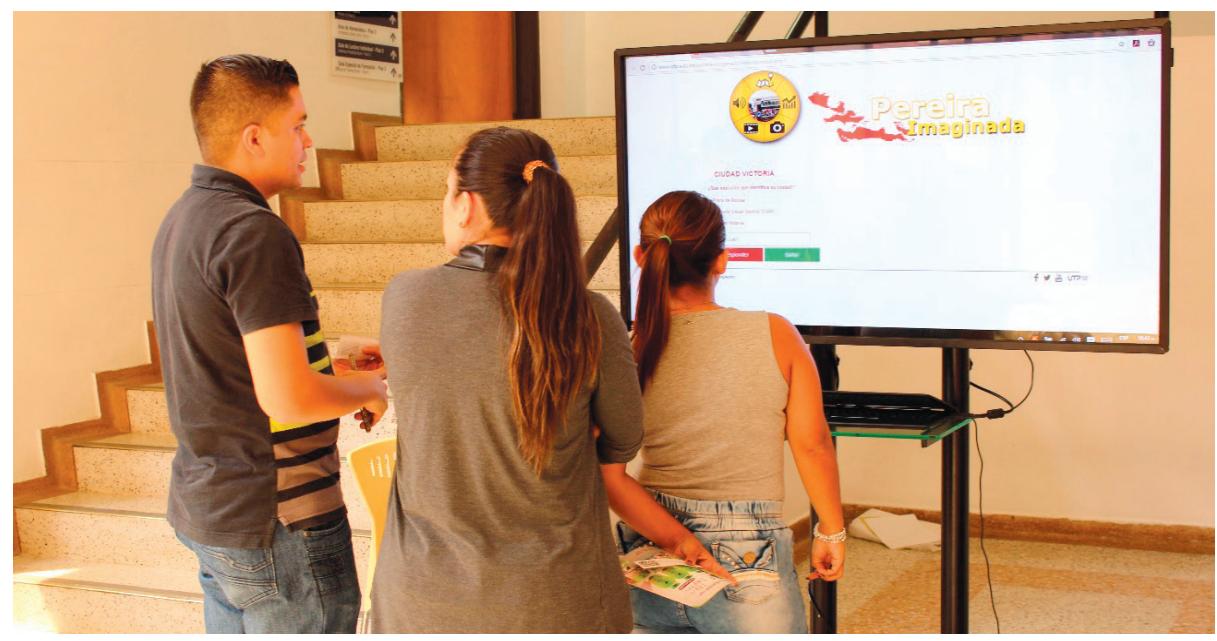

(a)

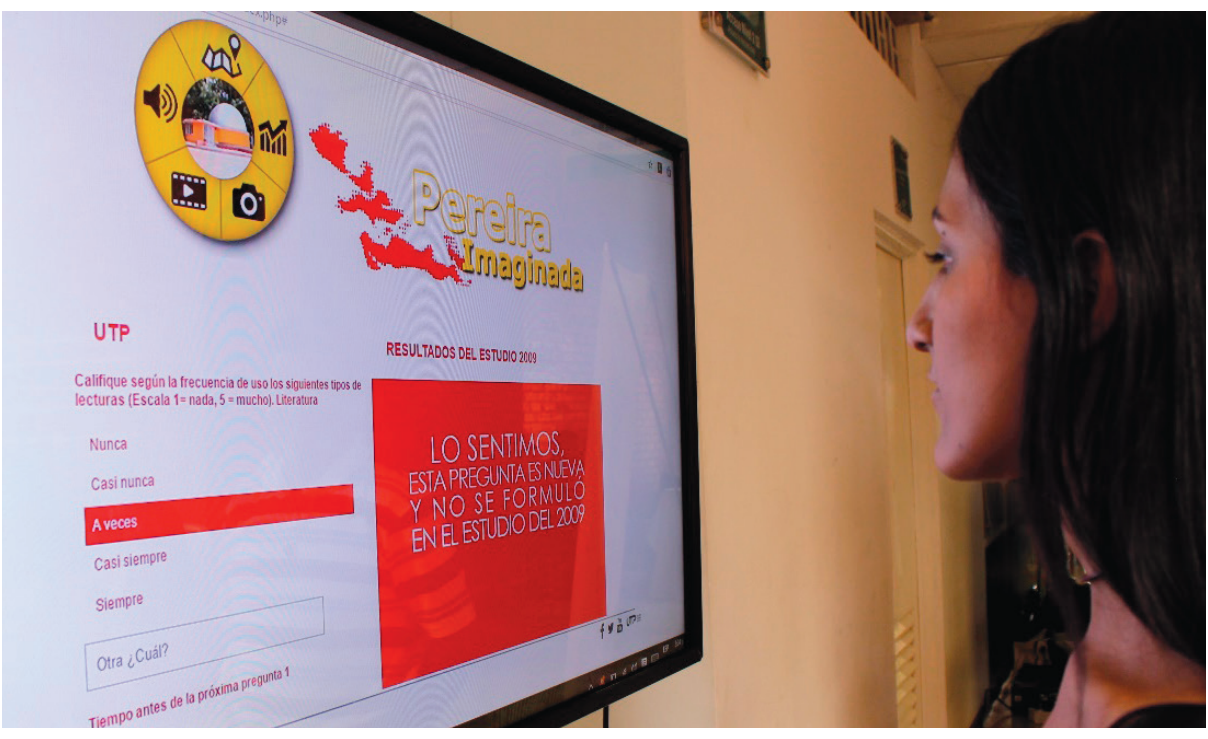

(b) 


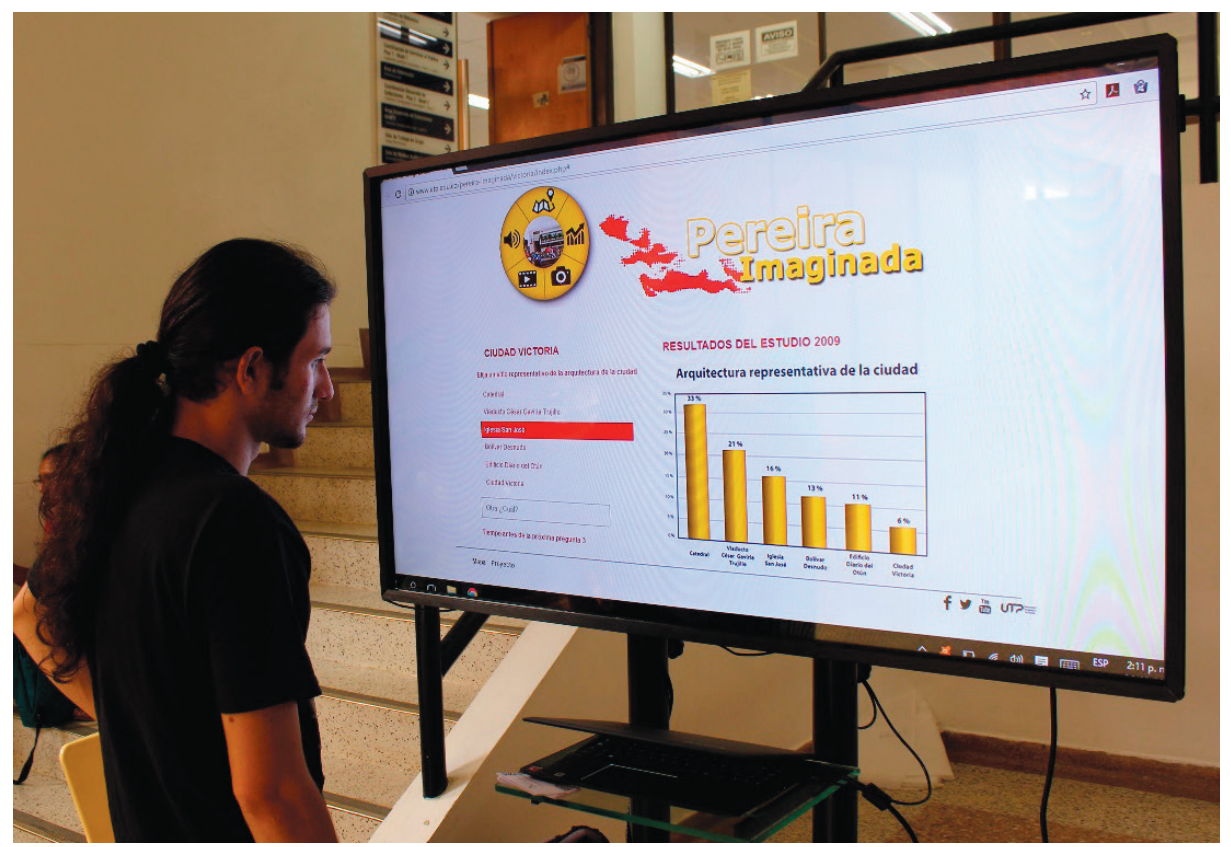

(c)

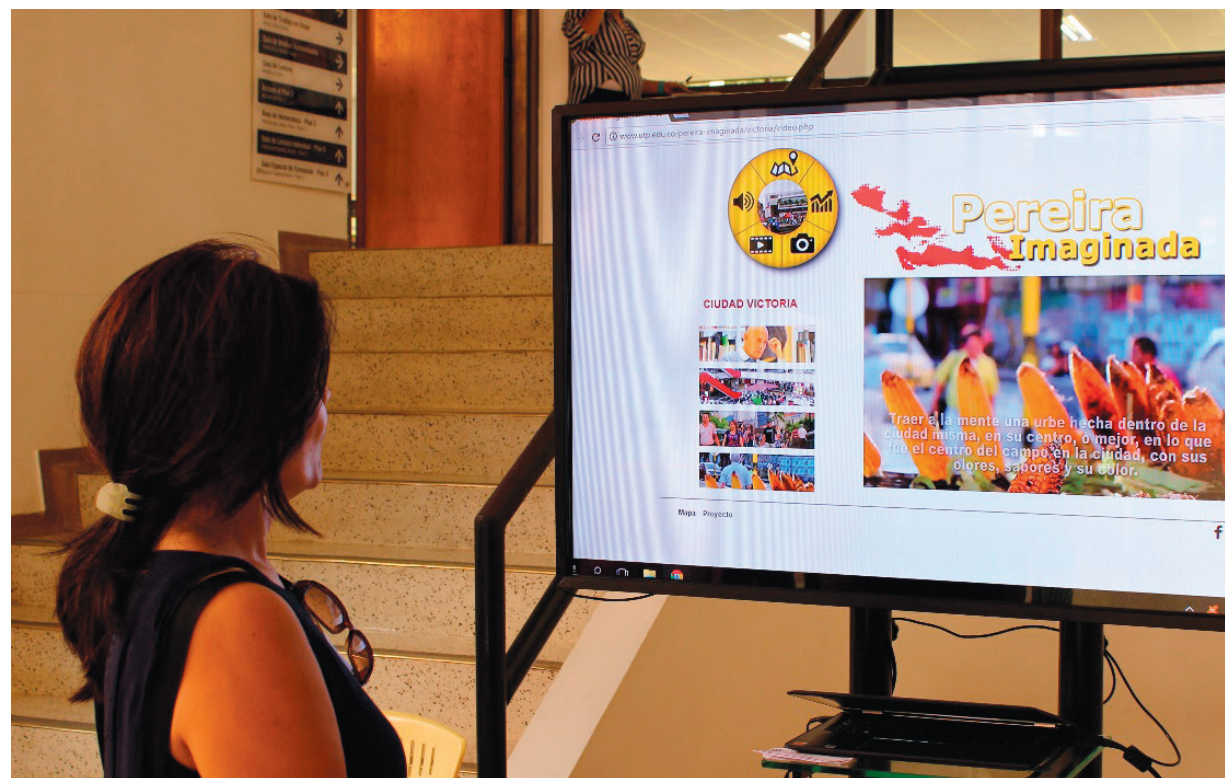

(d)

Fuente: Miguel Puentes 
Lo novedoso de la plataforma radica en las preguntas que la herramienta anida. Son ellas las que permiten capturar en vivo y en directo las respuestas de los sentires ciudadanos, al tiempo que derivan resultados sistematizados en la base de datos de Excel, pudiendo mostrarle al visitante los histogramas de todos los ciudadanos que han interactuado con la plataforma.

Otra de las novedades de la plataforma es que no solo se puede consultar presencialmente sino también por medio de un enlace de Internet (https://www.utp. edu.co/pereira-imaginada/\#modal). 




\section{TERCERA PARTE}





\section{Resultados: croquis de la ciudad de Pereira}

Llegados a este punto construimos los croquis de ciudad, o sea, las configuraciones afectivas que los ciudadanos expresan al evocar una respuesta, la cual es una declaración asertiva producto no solo de su mundo experiencial. Como dice Silva (2007), así se forman los imaginarios, como una forma de conocer el mundo.

Como ya se dijo en el enfoque teórico, los imaginarios, a veces, tienen un sustrato empírico, que los enmarca en lo que Silva denomina ciudad imaginada como modelo encarnado. Es desde este modelo que construimos los croquis de ciudad:

- $\quad \mathrm{R} \sim \mathrm{I}$ (realidad similar al imaginario): indica que lo que se halla en la realidad corresponde con el imaginario.

- $\quad \mathrm{R}>\mathrm{I}$ (realidad mayor que el imaginario): indica que existen en la realidad, pero no en el imaginario.

- $\quad$ I > R (imaginario mayor que la realidad): el imaginario es mayor que la realidad.

Los croquis que presentamos corresponden al conjunto de respuestas obtenidas en las diferentes preguntas, esto es, lo que representamos no obedece a una preguntarespuesta, sino a que una respuesta tiene relación con varias preguntas. El esquema es el siguiente: 
Figura 15. Esquema de análisis de datos

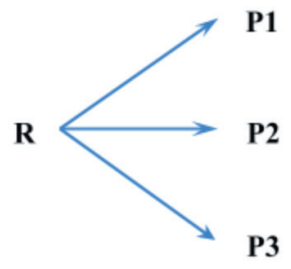

Fuente: archivo particular del proyecto de investigación

\subsubsection{Croquis de sitios de cercanía/lejanía afectiva10}

La convención de los croquis son los óvalos puntuados, los cuales encierran una diversidad de lugares físicos, en algunos casos; o sentires, emociones, en otros casos. La categoría lejanía/cercanía afectiva con los sitios que nombran los ciudadanos encierra el sentir sobre las zonas tristes/alegres, peligrosas, del peor/mejor olor, lugares que no gustan/gustan.

Si la tristeza se asocia con la muerte, la alegría se relaciona con la fiesta, la diversión y el consumo. Los olores se relacionan con aquellos lugares que poseen un aroma característico, ya a comida (Chorilago), ya a personas (prostitutas, inseguridad), ya a ambientador (centros comerciales). Los sitios que gustan se identifican con las actividades que en ellos se practican, como la diversión, la educación y los centros comerciales, mientras que los que no gustan son los que evocan inseguridad.

Figura 16. Croquis de sitios de cercanía/lejanía afectiva

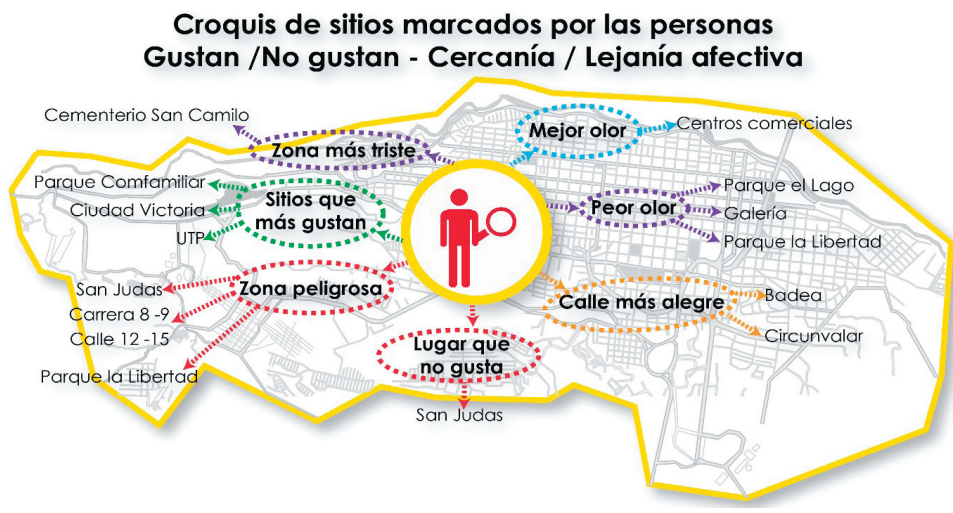

Fuente: Olga Lucía Bedoya y Miguel Puentes C. (2017)

10. En los croquis, la persona al centro representa la idea del ciudadano frente a lo que dice; los óvalos punteados encierran los croquis. 
Lo relevante al observar en este croquis es la extensión física o emocional que abarcan muchos puntos distantes en el mapa de la ciudad que está en el trasfondo. Por eso, la categoría croquis nos ilustra más que la de mapa. Aquellos encierran percepciones emocionales como se ve en la imagen, y desborda límites geográficos.

\subsubsection{Croquis sobre las cualidades de la ciudad}

El croquis de las cualidades de Pereira encierra las asociaciones que los ciudadanos hacen sobre el aspecto físico de la ciudad y sobre la noción de ciudadano que en ella habita; asimismo, también involucra los sitios que identifican a la ciudad, su color, su arquitectura, los lugares que se identifican con los viejos y jóvenes y el carácter de las personas.

Figura 17. Croquis de las cualidades de la ciudad

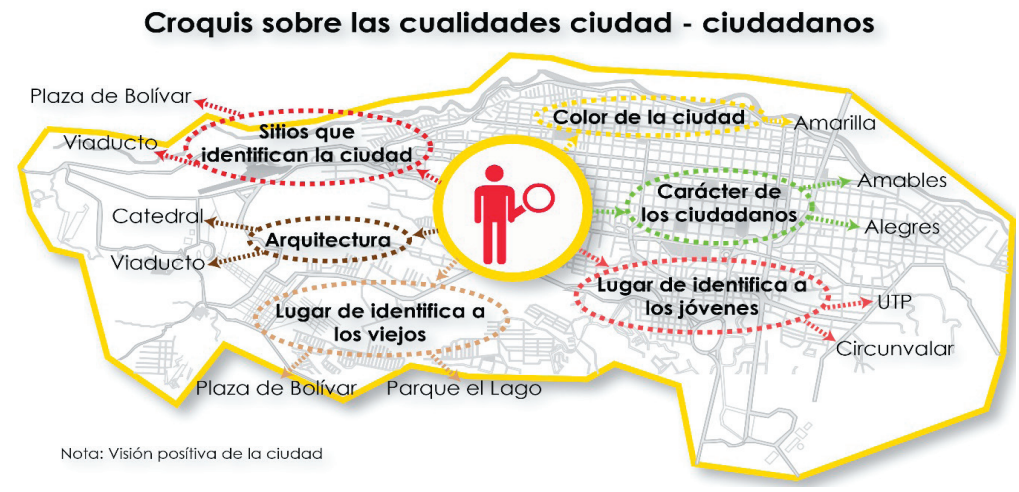

Fuente: Olga Lucía Bedoya y Miguel Puentes C. (2017)

Los lugares tradicionales/modernos ocupan un sitio en las evocaciones de los ciudadanos (Plaza de Bolívar, Catedral, Viaducto). También existen croquis de vejez/ juventud, de amabilidad/alegría y de color. El amarillo prevalece por sobre los demás colores y está asociado con los atardeceres y la alegría de la ciudad; de hecho, la luz y el Sol son las cualidades que enmarcan la alegría y amabilidad de los pereiranos. Como los parques son los lugares para el descanso de los viejos, se relacionan con la tranquilidad, con el trasegar por la vida y con el deber cumplido. A su vez, los jóvenes se asocian con un futuro en construcción en donde la educación es el horizonte que ayudará en ese camino; también es el periodo cuando la diversión es un complemento para la vida. 


\subsubsection{Croquis de calificaciones sobre los servicios para el ciudadano}

Los ciudadanos construyen un croquis alrededor de los servicios que contribuyen a su bienestar en la ciudad, por tanto, los ciudadanos califican aquellos que tienen más afectividad por lo que atañen a la vida misma.

Figura 18. Croquis de las calificaciones de los servicios para los ciudadanos

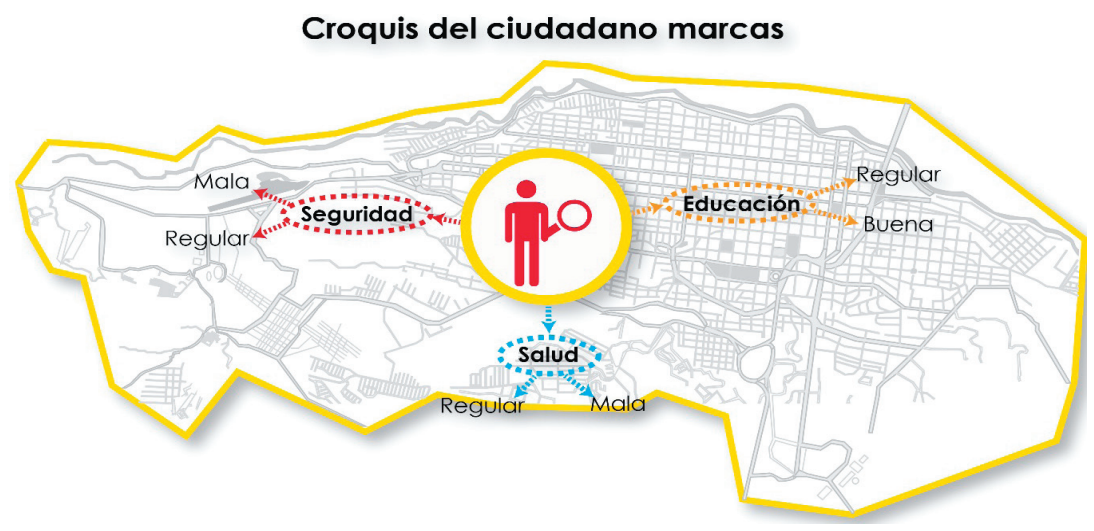

Fuente: Olga Lucía Bedoya y Miguel Puentes C. (2017)

Los imaginarios sobre la seguridad/inseguridad, la educación y la salud constituyen un croquis de calificación sobre lo bien, regular o mal que esos servicios se prestan. Los ciudadanos evocan el derecho que tienen a disfrutar de esos bienes y, por tanto, la cercanía o lejanía está definida por su cumplimiento/incumplimiento. En este imaginario, los sustratos empíricos son evidentes para tomar tal posición; las noticias, la vivencia personal, las reformas son índices que acrecientan dichos croquis.

\subsubsection{Croquis de calidad de vida en la ciudad}

El croquis de la calidad de vida de Pereira trasciende las afectividades cercanas sobre ese bienestar. Esta inferencia encuentra sustento en la comparación de los croquis de las cualidades de la ciudad y el carácter de los ciudadanos con el de calificaciones. Si bien en este último existe la sensación de que falta algo, no es el criterio para pensar en una calidad de vida menguada. Y es que el sentir ciudadano se corresponde con las estadísticas del informe «Pereira Cómo Vamos» (2015 y 2016), en el cual se establece que la calidad de vida de la ciudad es muy buena. 
Figura 19. Croquis de calidad de vida

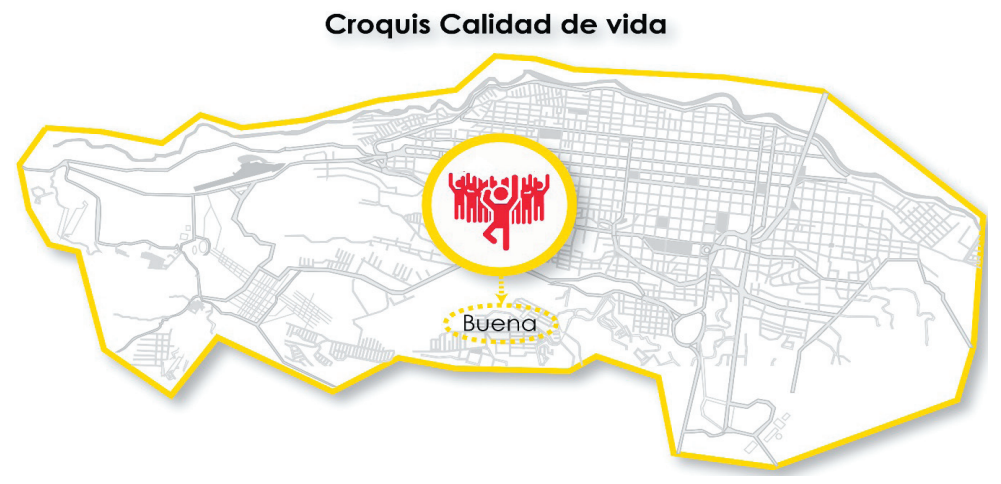

Fuente: Olga Lucía Bedoya y Miguel Puentes C. (2017)

Tener una posición positiva frente a la calidad de vida de Pereira trasciende el hecho de los indicadores que solo miden factores económicos o externos a la persona. Si bien en la ciudad de Pereira existen carencias en el entorno, como falta de empleo, salud y seguridad, otros factores, como el estado psicológico de sentimientos positivos, de relaciones familiares y sociales, espirituales, entre otros, resultan bien valorados a la hora de calificar esta calidad.

El criterio, entonces, de calidad de vida para los ciudadanos, esta medido por la cercanía que existe en Pereira entre todos los sitios, lo que disminuye el tiempo de desplazamiento, y el invertido en cada una de las actividades. Es decir, en unas pocas horas, se puede hacer la mayoría de los compromisos cotidianos; otro aspecto, es poder ir almorzar a la casa, la mayoría de lugares se desocupan a medio día, por lo tanto, "la siesta se incorpora"; esto permite compartir con la familia o amigos en estos momentos. Así, mismo, existe una relativa cercanía con Medellín, Bogotá, Manizales, Cali, Armenia, tanto por vía terrestre, como por la frecuencia de aviones. Todos estos índices, marcan una sensación de bienestar. Pues se vive con el gran imaginario de estar en una metrópoli, aunque la vida transcurra en una localidad pequeña.

\subsubsection{Croquis de experiencias personales}

Los ciudadanos establecen rutinas alrededor de sus actividades personales. Al indagar por ellas, encontramos que el computador, la Internet y el celular se convierten en sus acompañantes, así como la lectura y la literatura. 
Figura 20. Croquis de experiencia personal

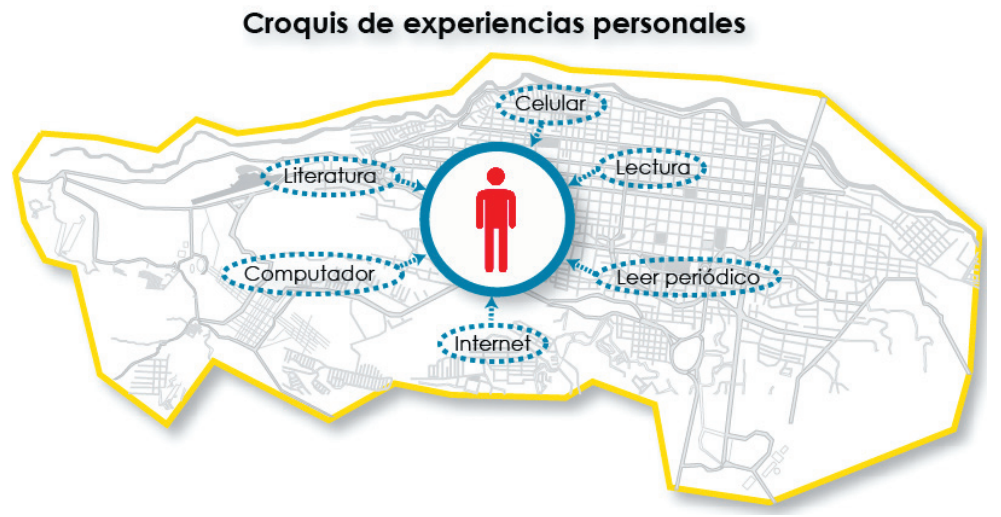

Fuente: Olga Lucía Bedoya y Miguel Puentes C. (2017)

Observando el croquis, el ciudadano, está envuelto en un entorno telecomunicativo mediante el cual puede acceder desde su localidad al mundo, por los diferentes medios al que tiene acceso.

\subsubsection{Croquis del uso de la televisión}

Una de las rutinas identificadas en los ciudadanos es el uso de la televisión. A pesar de la penetración de otras formas y medios de entretenimiento, la televisión continúa vigente. Las indagaciones evidencian que la incorporación de la interactividad en la televisión - por ejemplo, a través de las redes sociales - también ha refrescado el medio.

Lenta pero inexorablemente la televisión pública está siendo desplazada por los canales por suscripción. De la televisión pública, los noticieros son los de mayor consumo, seguidos por el entretenimiento. El medio día y la noche son los periodos más usados para ver los noticieros.

Pereira aún se caracteriza por los cortos desplazamiento. La cercanía entre la casa y el trabajo o la escuela, por ejemplo, todavía permite que la mayoría de los ciudadanos almuercen en su casa. 
Figura 21. Croquis de rutinas alrededor del uso de la televisión

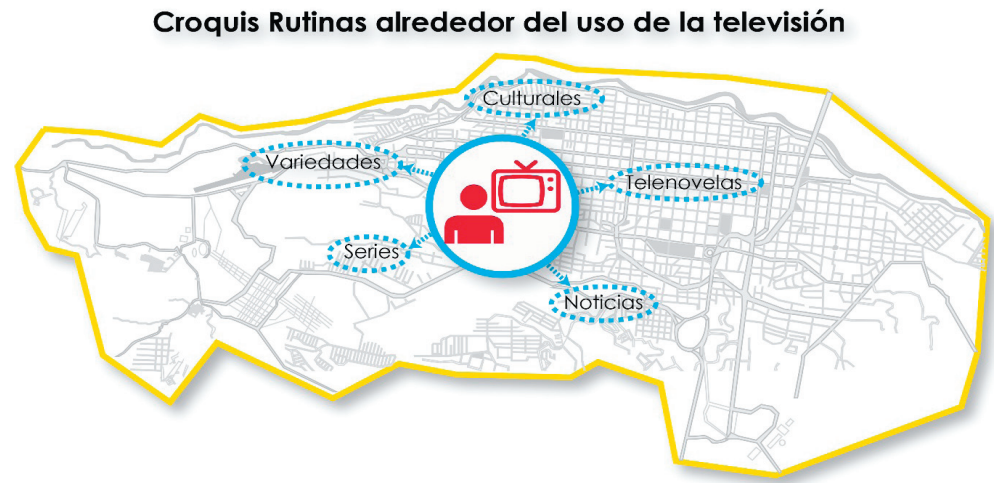

Fuente: Olga Lucía Bedoya y Miguel Puentes C. (2017)

El entretenimiento es uno de los elementos que la industria cultural explora con mayor beneficio, sustentada en las preferencias del público por el disfrute emocional y sensorial. De allí que las series, las variedades y las telenovelas aún ocupen un lugar importante en las rutinas televisivas de las personas.

\subsubsection{Croquis del uso del tiempo libre}

Como se ha dicho, reflexionar en torno a los croquis ciudadanos no solo comporta referirse sobre las partes físicas de la ciudad, sino que también incluye a los urbanismos ciudadanos. O como lo expresa Silva (2004), lo experiencial se vive desde lo vivido y lo no vivido.

Figura 22. Croquis del uso del tiempo libre

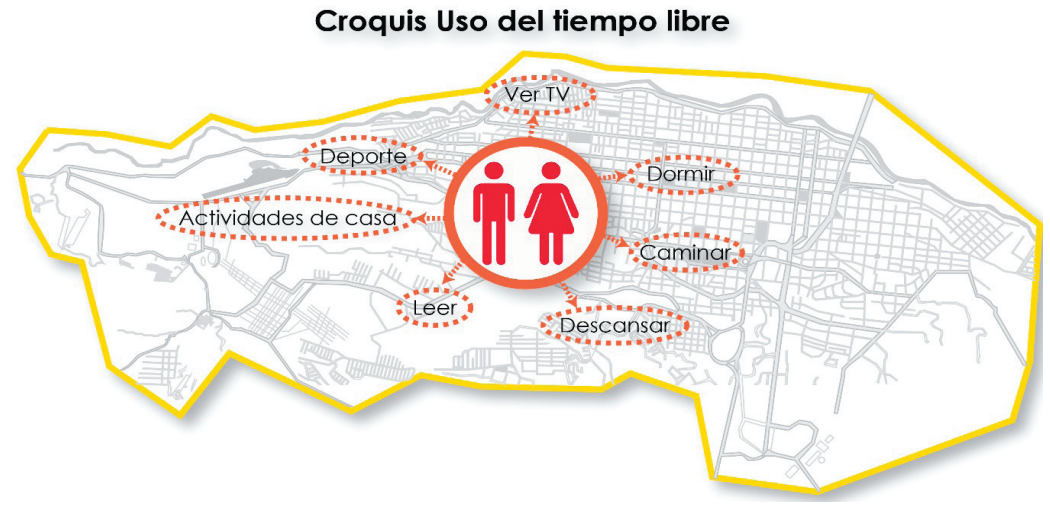

Fuente: Olga Lucía Bedoya y Miguel Puentes C. (2017) 
Actividades como dormir, caminar, descansar, hacer deporte, leer o ver televisión son las rutinas que marcan ser ciudadano de Pereira. Al estar relacionadas con el uso del tiempo libre, son prácticas que redundan en la calidad de vida de los ciudadanos, y que atañen directamente a factores psicológicos, espirituales y del entorno (doméstico, recreación, seguridad física).

\subsubsection{Croquis sobre el cuidado del cuerpo}

El cuidado del cuerpo es una actividad que la humanidad siempre ha privilegiado, pues tiene que ver con factores como la estética, la salud o el canon de belleza establecido (representación que tiene cada sociedad acerca de lo que es bello o bueno). Por ejemplo, en la cultura griega, los gimnasios eran considerados espacios destinados a cultivar el cuerpo y cuidar la salud. Ahora, más de dos mil años después, la cultura de las cirugías "estéticas" ha hecho del cuerpo un escenario para la alteración y la experimentación, en un fatuo intento por borrar las huellas que sobre la piel deja el paso del tiempo. Con todo, a la par de una búsqueda cosmética, la idea de cultivar el cuerpo, por salud y belleza natural, pervive.

Figura 23. Croquis del cuidado del cuerpo

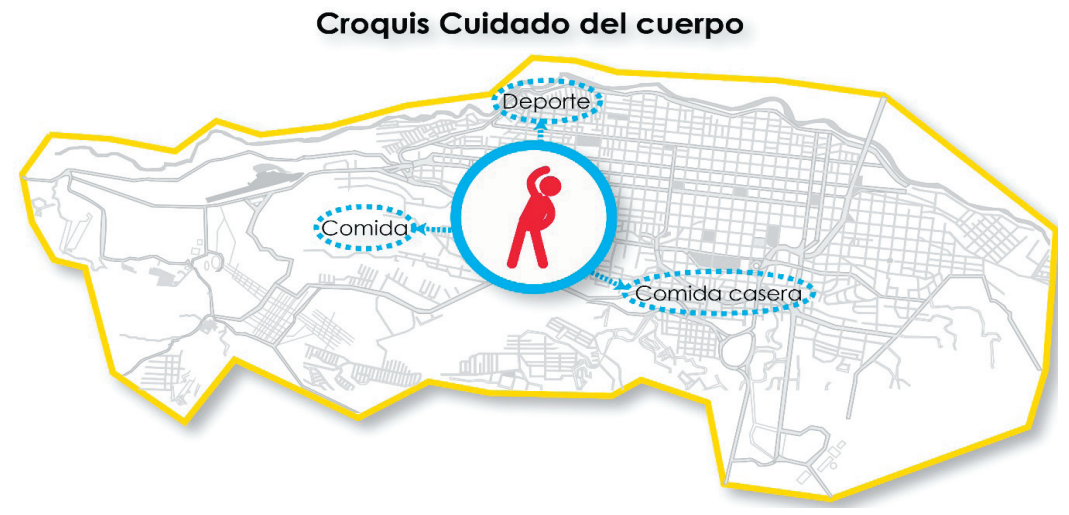

Fuente: Olga Lucía Bedoya y Miguel Puentes C. (2017)

El deporte y la comida casera son dos factores que los pereiranos conciben como formas de cuidar el cuerpo. Pereira, de hecho, es una ciudad que también ha incursionado en el mundo de las cirugías estéticas, pero en nuestra indagación esta actividad aparece como un residuo (baja tendencia) en la percepción y, por tanto, todavía no hace parte de los imaginarios de ciudad. 


\subsubsection{Croquis de vida en pareja}

Otro de los factores de la calidad de vida considerados mundialmente es la seguridad afectiva que las personas buscan. Cada sociedad ha construido su concepción de pareja y ha determinado las funciones (roles) que sus integrantes cumplen al interior de esa relación.

Figura 24. Croquis de vida en pareja

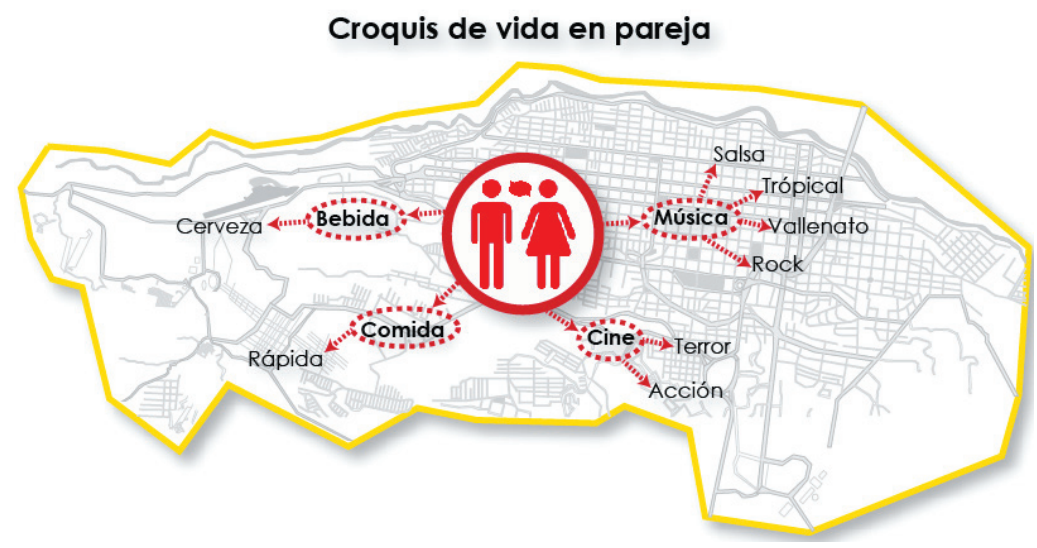

Fuente: Olga Lucía Bedoya y Miguel Puentes C. (2017)

Al indagar por las rutinas de pareja de los pereiranos, se encuentra que las han incluido como parte central del imaginario. Las vivencias con la pareja se dan, principalmente, alrededor de la bebida, la comida, la música y el cine. Igualmente, los croquis sobre la bebida de cervezas, las comidas rápidas y el cine de terror y acción, así como géneros como la salsa, el tropical, el vallenato y el rock caracterizan unas rutinas imaginadas, que complementan a aquellas que se desarrollan en el tiempo libre, relacionadas con el cuidado del cuerpo y las actividades individuales.

\subsubsection{Croquis de experiencia personal del uso de la ciudad}

Los croquis hasta aquí descritos son producto de vivencias directas o indirectas de los ciudadanos. Ahora, los que siguen, hacen parte de sus imaginarios sobre lo que perciben a propósito del uso de los espacios físicos de la ciudad y lo que ella ofrece. 
Figura 25. Croquis de experiencia personal en el uso de la ciudad

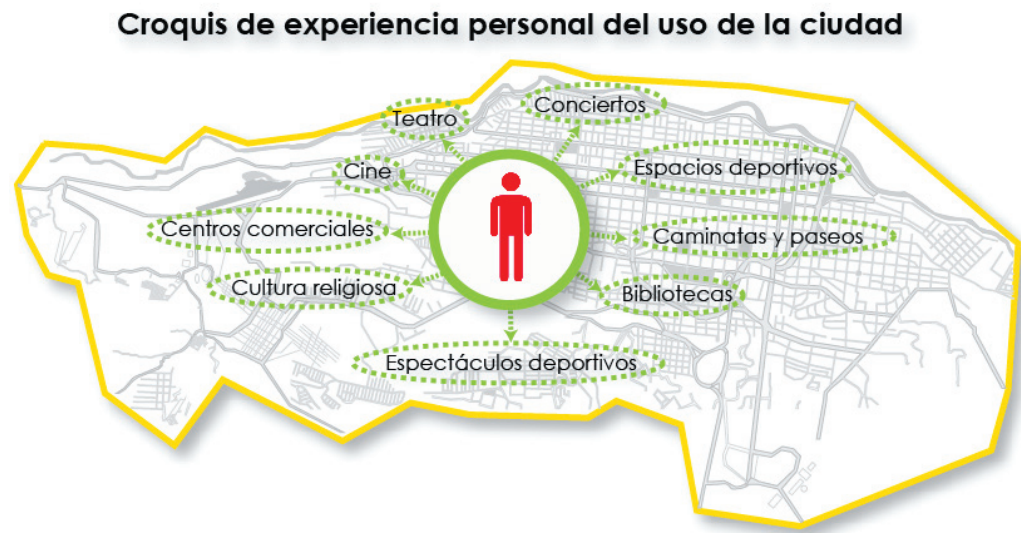

Fuente: Olga Lucía Bedoya y Miguel Puentes C. (2017)

Las rutinas que forman croquis son los teatros, el cine, los conciertos, los espacios deportivos, las caminatas, los paseos, las bibliotecas, los centros comerciales, la religión, los espectáculos deportivos. Todos ellos muestran el uso o evocación de las ofertas comerciales, culturales, recreativas o espacios que ofrece Pereira.

\section{A modo de cierre de la construcción de croquis}

Para concluir este recorrido por los croquis imaginados/vividos de alegrías, tristezas, bebidas, malos o buenos olores, cuidados del cuerpo, comunicaciones, diversiones, entretenimiento, tiempo libre, vivencias con la pareja, juveniles, de vejez, tenemos un panorama no solo de ciudad sino de urbanismos ciudadanos, el cual, desde la teoría del conocer de los imaginarios propuestos por Silva, se sustentan en la categoría otredades. Es en esta categoría donde lo expresado incorpora no solo lo que vivo sino lo que me imagino que vive el otro. Por ejemplo, quien percibe que el cuerpo se cuida desde la alimentación o el deporte, no necesariamente lo experimenta; la persona que responde no necesariamente lo vive sino que lo percibe como un sentir colectivo, o, quizás, lo manifiesta desde unos deseos que tal vez se volverán realidad en el futuro. Es esta la complejidad que se propone entender a partir de los croquis, que no son otra cosa sino recorridos afectivos.

Volvemos la mirada hacia las propuestas sobre la ciudad (capítulo 1), para mostrar la diferencia con ellas. Si bien en la Escuela de Chicago (1940) se introduce la concepción de asentamiento humano como comunidad, la noción se trató desde la perspectiva del apego territorial y la demarcación física del mismo, a partir de lo cual se definía la ciudad con criterios geográfico-espaciales. A su vez, las investigaciones sobre ciudad desarrolladas en Inglaterra hicieron énfasis en los migrantes. El motivo: la creciente urbanización de la ciudad a costa del despoblamiento del campo, situación que la nación experimentó durante los años cuarenta. 
La discusión sobre la dualidad ciudad/campo tomó su lugar en los estudios de ciudad, y diversos estudios específicos se fueron realizando. Entre ellos se cuentan los desarrollados por Balandier (1969), que giraron en torno del poder en el manejo de las comunidades; los de Lefvre (1967), con sus estudios de la vida cotidiana; los de Canclini (2005), con su propuesta de cultura híbrida, concepto que propone para nombrar el producto de la entremezcla cultural y la emergencia de nuevas configuraciones, emanadas de los múltiples grupos que habitan de la ciudad; los de Reguillo (2005), con su tema sobre los acontecimientos (desastres, violencia como respuesta ciudadana).

Todas estas investigaciones trataron de explicar los fenómenos que acontecían en la ciudad a partir de diferentes categorías teóricas. Pero dejaban sin embargo por fuera el punto de vista ciudadano, que también es una forma legítima de conocer el mundo. En esta perspectiva se ubica la investigación del mexicano Ernesto Licona (2003), que versó sobre el conocimiento del barrio, a partir de los dibujos de sus habitantes. Desde allí, a través de huellas imaginarias, arraigadas a un territorio físico, los ciudadanos reconstruían su memoria. Ya desde los años ochenta Armando Silva venía preocupado por las estéticas ciudadanas expresadas a través de los grafitis, entendidas como intervenciones que mostraban un deseo ciudadano, que traspasaba las fronteras geográfico-espaciales. Desde ese lugar, Silva fue observando que las estéticas eran una forma de conocer y apropiar la ciudad, y que los grafitis eran un recurso ciudadano para marcar la ciudad, no solo desde la crítica sino también desde las apuestas futuras, expresadas en deseos. Silva advirtió que estas marcas estetizadas eran el fruto no solo de las experiencias vividas sino de las evocaciones de un futuro mejor, la cuales fueron paulatinamente migrado hacia lo virtual y trascendiendo lo geográfico-espacial. Como resultado, para referirse a la extensión mental, virtual y física de la ciudad, Silva propone el concepto de urbanismos ciudadanos. Como esta estética quedaba constreñida a la realidad misma, era necesario proponer otro término que diera cuenta de las transformaciones contemporáneas.

Así pues, los croquis que en este documento presentamos son vivencias del afecto, e indican la forma como los ciudadanos viven la ciudad, tanto imaginaria como realmente. Se destaca que para la construcción de los croquis priman el afecto y la inclinación ciudadana concreta, por sobre las directrices de orden institucional, que se caracterizan por su perfil abstracto. Comprender los croquis nos invita a repensar los criterios de verdad/falsedad en cuanto concepciones que llevan, la mayoría de las veces, a descartar en la configuración de la ciudad lo que piensa, entiende y siente la gente.

Como dice Silva (2007), lo imaginado es de un «orden distinto del puramente racional, se trata de una manera de conocer y de sentir al mismo tiempo, y por esto cabe usar una frase determinante para calificarlo: es una teoría de los sentimientos y de su expresión colectivas» (p. 89).

Ahora bien, para terminar de exponer la idea de urbanismos ciudadanos y croquis, proponemos una explicación desde la categoría compleja self, ésto se hace necesario por la complejidad que se observa en la percepción de los ciudadanos, la cual se constanta en sus respuestas, que contienen tanto una experiencia vivida como imaginada socialmente. Por lo tanto, esa categoría que proviene del inglés, da elementos explicativos a la forma como construimos una realidad a partir del Yo/Mí, como unidad indisoluble, que se puede distinguir pero no disociar. 



\section{CUARTA PARTE}





\section{El self y la explicación de los croquis}

El texto de George Herbert Mead, Mind, Self, and Society: The Deffinitive Edition (2015), plantea la discusión sobre la comprensión del self como unidad entre el yo/mí, la cual es central para concebir tanto lo colectivo que está en el mí, como la impronta que le coloca a ese mí el yo. Para entender este planteamiento, iremos construyendo parte del pensamiento del autor, para luego conectar esas ideas con los croquis urbanos.

Las ideas que nos enlazan los resultados de los croquis a partir de la percepción ciudadana y la teoría sobre el self, se refieren a la categoría de otredad propuesta por Silva, la cual se enmarca en las preguntas por ¿cómo creo yo que el otro me ve?, ¿cómo veo yo al otro? y ¿cómo me veo yo con respecto al otro? Son interrogantes que conllevan el sentir de lo vivido (pasado), lo que se vive (presente) y los anhelos (futuro).

En los croquis, se distingue, lo que Mead denomina la diferencia entre el cuerpo y el conocimiento. Esto es, el ciudadano refiere una realidad independiente de si él tuvo una experiencia directa con ella o no, es decir, en la toma como verdad, pero su cuerpo no necesariamente pasó por la experimentación.

Al respecto, Mead (2015) plantea:

We can distinguish very definitely between the self and the body. The body can be there and can operate in a very intelligent fashion without there being a self involved in the experience (p. 64).

En este contexto, Mead (2015) enmarca la idea de la simultaneidad entre el sujeto y el objeto a través de la palabra self, palabra que resulta reflexiva pues indica alude a ambas realidades. Al respecto, Mead observa: «It is the characteristic of the self as an object to itself that I want to bring out. This characteristic is represented in the word "self", which is a reflexive, and indicates that which can be both subject and object (p. 64).

Ahora bien, el self surge en lo social, en lo colectivo (objeto), pero, igualmente, una vez aparece, puede marcar su impronta, la diferencia con ese yo-colectivo (sujeto). 
Así podemos entender, cómo los ciudadanos coinciden en apreciaciones sobre buenos/malos olores de lugares; calles con más alegría, más peligrosa, lugares tristes, las cuales no necesariamente tienen esas características, ni tampoco, los conocen en mucho de los casos, sin embargo las toman como realidades existentes.

Lo central en el planteamiento de Mead es la idea de la complejidad del yo (self), en la medida que es un reflejo de los procesos sociales, en tanto que estos son creados por los humanos, pero se vuelven como una realidad a parte de ellos- los humanos- (yocolectivo) y a su vez, el yo (subjetivo) puede tomar conciencia de esos mismos procesos sociales y funda otros nuevos a partir de ellos mismos.

En este orden de idas, el autor propone la reflexión sobre la "conciencia" (nosotros solos tenemos acceso a ella), tomándola como un pensamiento o inteligencia reflexiva, lo que implica la referencia a un "yo en eso" ( $\mathrm{I}$ in it), que es una idea diferente a la tendencia de la psicología. Cuando el autor habla de la relación entre el self y la conducta, solo lo hace en un cierto orden de ideas, esto es, con lo que tiene que ver con la interacción humana en una actividad cooperativa donde el self puede crecer.

En los croquis se observa esta diferencia en la medida que no los podemos referir a la conducta individual sino que son producto de un colectivo y su imaginación frente a lo que creemos hace el otro/yo.

Estas ideas las expresa el autor, al distinguir ente dos cosas: por un lado, el self y su relación con los procesos sociales y por el otro, la conciencia con que son experienciados los objetos (experiencia con los objetos). Así, con Mead se distinguen aquellas atmósferas con las que el self está en contacto pero no tiene una experiencia con ellas, y las experiencias que el sujeto ha tenido directamente con ellas (subjetividad): experiencia reflexiva. Igualmente, a las imágenes que se nos vienen a la memoria solo podemos acceder individualmente.

En síntesis, el autor quiere marcar la diferencia entre el orden de la estructura social donde crece el self y la experiencia subjetiva donde él accede solo sin fundirse con el otro (la interacción social). El self toma de ese orden social actitudes que se reflejan en su conducta, y actúa de forma similar con los demás.

Pero también está ese otro yo, que cuando habla con la voz y la razón de sí mismo (himself), va en contra de lo común: es su voz, antes que de la comunidad. Ese yo toma su pasado-futuro y cambia el orden de las cosas. Es conciencia de la conciencia. Así se cambia, porque se piensa inteligentemente.

Al llegar a este punto de la reflexión podemos introducir los términos que están incluidos en el self y que distinguen ambas experiencias: el yo colectivo y el yo individual, fusionados totalmente. Mead denomina al primero como el "me" y al segundo como el "I", ambos contenidos en la palabra self.

Dice Mead que el "me" se manifiesta cuando reaccionamos en una situación de la forma como todo el colectivo lo haría; es lo esperado. En tanto que el "I", ante el mismo escenario, toma otros caminos inesperados, aportando otra manera de ver lo mismo: " "I" which is aware of de social "Me"» (p. 81).

Podemos, entonces, comprender que el self es un proceso social, en el cual se diferencian dos momentos en la acción: el primero es el "I" (yo subjetivo), que es impredecible y puede introducir un elemento nuevo en el comportamiento; el segundo 
es el "Me" (yo colectivo), que es predecible, se incorpora mecánicamente y actúa como está indicado. Al poder distinguir estos dos procesos, que aparentemente están en uno solo, existe una responsabilidad consciente frente a la respuesta en una situación determinada, y, además, habría novedad en la experiencia. De lo contrario, no se dará ni la una (responsabilidad) ni la otra (novedad).

Durante esta reflexión recurrimos al término self porque recoge las dos realidades que presenta nuestra experiencia de vida. Se optó por el término self en lugar de "yo" (primera persona) porque el segundo término solo recoge una de las posibilidades. El "yo" se ha borrado de la escritura científica para darle entrada al pronombre "nosotros", término que subsume al "yo"; empero, si no se lo menciona o evoca, las más de las veces no está, no aparece.

Ahora bien, ¿cómo se relaciona la discusión sobre el self y los croquis? La relación entre el self y los croquis la establecemos en la percepción del ciudadano, hecho que conlleva una forma de conocer gracias a que se reconoce la existencia de algo a partir de su propia experiencia y/o desde lo imaginado de los otros. ¿Cómo negar la existencia de las percepciones imaginado/vivido, de las alegrías, las tristezas, las bebidas, los malos o buenos olores, del cuidados del cuerpo, de las comunicaciones, las diversiones, el entretenimiento, el tiempo libre, las vivencias con la pareja, las ideas sobre lo juvenil, la vejez? Quien percibe y sugiere que el cuerpo es cuidado desde la alimentación o el deporte no necesariamente lo experimenta, ya que lo puede percibir como un sentir colectivo, o quizás desde los deseos que, tal vez, se volverán realidad en el futuro.

Ahora bien, la anterior relación nos habilita para desmarcarnos de la idea positivista de calificar las percepciones como verdaderas o falsas, a causa de que dicho binarismo niega la complejidad del self.

Las percepciones existen y obedecen a diferentes órdenes que se funden en uno solo: el self. Desde este punto de vista, siguiendo a Peirce (1894, p.6), en lo dicho podemos encontrar índices de existencia o de posibilidad de existir de algo-alguien y, por tanto, de asumir una posición frente al mundo, no solo desde el Me (lo que dice el colectivo) sino también desde la libertad del Yo (innovador-impronta), y trascender así la calificación de falso o verdadero frente a una posibilidad de existencia.

Desde esta postura, los croquis descritos no solo llevan consigo el self (yo/ mí), sino que dan la posibilidad de incorporar a nuestro conocimiento las realidades imaginadas de los urbanismos urbanos, como algo presente/futuro/presente.

\section{A manera de conclusión}

Una vez se termina el recorrido por la investigación Pereira Imaginada, y los croquis resultantes de la misma, nos queda la pregunta por la utilidad de un trabajo como éste.

El aporte lo ubicamos en dos esferas: una teórica; y la otra, de carácter práctico; ambas esferas se encuentran interrelacionadas. En el primer caso, compartimos el enfoque filosófico que concibe la realidad como una construcción social, de allí la importancia del concepto de imaginarios urbanos propuesto por Armando Silva. Esta concepción se aparta de la idea tradicional de la realidad como algo dado, por fuera del sujeto, donde éste solo la describe y la cuantifica. La posibilidad de incorporar 
esta visión, nos permite, observar el dinamismo social, el cambio; y al mismo tiempo, aquello que continua y se repite. Esto se distingue en el cambio de percepción de los ciudadanos frente a su cotidianidad; por lo tanto, la construcción de croquis es una tarea constante, que valida la continuidad de la investigación. Es decir, lo que hoy se identifica puede no estar mañana, o haberse transformado o desaparecido y, por tanto, emerge algo nuevo. Esto nos permite incorporar la mirada diacrónica a estos estudios sincrónicos, y de esta manera observar las transformaciones de la ciudad y los urbanismos ciudadanos en una línea temporal. Y como diría, Niklas Luhmann (1988), encontrar en esos procesos históricos, enlaces comunicativos para comprender tanto el pasado como el futuro a partir del presente.

La segunda utilidad, es de carácter político, específicamente, las prácticas convencionales implicadas en ésta. En el caso de los imaginarios urbanos, los croquis se convierten en una posibilidad para quienes dirigen los destinos locales, en el sentido de identificar las realidades construidas por los ciudadanos e incorporarlas a sus propuestas, desde las siguientes reflexiones:

1. Qué imaginarios-croquis se pueden intervenir para cambiarlos, desde una concepción de bienestar para los ciudadanos.

2. Qué imaginarios -croquis, se reforzarían dada la importancia para la calidad de vida

3. Qué nuevos imaginarios-croquis se podrían crear en pos de la calidad de vida.

Esta forma de hacer política, estrecharía la brecha entre quienes se suben al poder con unos imaginarios alejados de la vida cotidiana, y la realidad misma. Porque, el sentido de tener una democracia, es precisamente, la inclusión de la diferencia y los antagonismos, tal como lo plantea Chantal Mouffe (2011); lo cual conlleva la incorporación del dinamismo social que establece órdenes temporales. Pensar así, permitiría incluir los conflictos y a su vez la mitigación de los mismos, que precisamente, se presentan por la exclusión de la diferencia.

Las anteriores reflexiones, son las que permiten que las investigaciones sobre los imaginarios urbanos como construcciones sociales tengan relevancia permanente, y de allí la importancia del formulario base que se anidó en la plataforma virtual, en la medida que capta el punto de vista ciudadano cada vez que se usa ésta. 




\section{REFERENCIAS}



Bedoya, O., Castiblanco, A., Zuluaga, V., Maldonado, F. y Patiño, F. (1999). Imaginario femenino y ciudad: Pereira y su evocación de mujer. Bogotá: Tercer Mundo Editores.

Bedoya, O., Castiblanco, A. Jaramillo, C., Verón, A. (2006) Memoria y ciudad: Pereira post-sísmica 2001 - 2006. Pereira: Publiprint.

Bedoya, O. L. (2011). Pereira Imaginada (Vol. I). (A. Silva, Ed.) Pereira, Risaralda, Colombia: Publiprint.

Boone, E. (1998). Stories in Red and Black: Pictorial Histories of the Aztecs and Mixtecs. Austin: University of Texas Press.

Bouchard, P. (2011). Las promesas de la red y sus implicaciones. En: El impacto de las redes sociales en la enseñanza y el aprendizaje [monográfico en línea]. Revista de Universidad y Sociedad del Conocimiento, 8(1), pp. 272-287, Universitat Oberta de Catalunya. Disponible en: http://rusc.uoc.edu/rusc/es/index.php/rusc/article/ download/v8n1-globalizacion-e-internacionalizacion-de-la-educacion-superior/10761504-2-PB.pdf

Berger, P. y Luckmann, T. (1966). La construcción social de la realidad. Buenos Aires: Amorrortu.

Cámara de comercio de Pereira. (28 de agosto de 2015- 2016). Pereira cómo vamos. Obtenido de http://www.pereiracomovamos.org/es/ia/informes/2015/informe_ calidad_de_vida/

De Benedetto, J., Bellavista, P. y Foschini, L. (2017). Proximity discovery and data dissemination for mobile crowd sensing using LTE direct. Computer Networks, 129 (part 2), Dec, pp. 510-521. Disponible en: https://www.sciencedirect.com/science/ article/pii/S1389128617303092

El Futuro Es Apasionante (4 de enero de 2017). Big data de las redes sociales para predecir el comportamiento ciudadano [archivo de video]. Disponible en: https://www. youtube.com/watch?v=yoSqojO2-CQ\&pbjreload=10

Grijalba, N. y Toledano, F. (2014). Nebrija Medialab: un valor añadido a la docencia y al desarrollo de competencias. Historia y Comunicación Social, 19(especial), feb, pp. 733-744. Disponible en: https://revistas.ucm.es/index.php/HICS/article/ viewFile/45061/42433

Houser, N. y Kloesel C. (Comp.). (2012). Obra filosófica reunida. Volumen II (1893-1913). Charles Sanders Peirce. México: Fondo de Cultura Económica. Disponible en: https:// 
books.google.com.co/books?id=1cAl90ounLMC\&printsec $=$ frontcover\&source $=$ gbs ge_summary_r\&cad $=0 \# \mathrm{v}=$ onepage $\& \mathrm{q} \& \mathrm{f}=$ false

Khettab, S. y Chabbi-Chemrouk, N. (2017). Sense of place in the coastal town of Tipaza in Algeria: Local-community`s socio-cognitive representations. 6(2), Dec, pp. 544-554. Disponible en: https://www.sciencedirect.com/science/article/pii/S2212609017300870

Mueller, J., Lu, H., Chirkin, A., Klein, B. y Schm, G. (2018). Citizen Desing Science. Cities, 72(part A), Feb, pp. 181-188.

Mead, G. H. (2015). Mind, Self, and Society: The Deffinitive Edition. Chicago: The University of Chicago Press, 536 p. Disponible en: https://books.google.com.co/ books?id=22jtBwAAQBAJ\&printsec $=$ frontcover\&redir_esc $=\mathrm{y} \# \mathrm{v}=$ onepage\&q\&f$=\mathrm{false}$

EAFIT. (17 de marzo de 2015). Universidad EAFIT. Obtenido de http://www.eafit.edu. co/medialab/acerca-de/Paginas/medialab-eafit.aspx

Montoya, D., Vásquez, M. y Salinas, H. (2013). Sistemas intertextuales transmedia: exploraciones conceptuales y aproximaciones investigativas. Revista Co-herencia, 10(18), ene-jun, pp. 137-159. Disponible en: http://www.scielo.org.co/pdf/cohe/ v10n18/v10n18a05.pdf

informe «Pereira Cómo Vamos» (2015 y 2016).

Roldán V, J. (2 de junio de 2011). Qué son los Living Lab. Colombia Digital. Disponible en: http://frajaro.blogspot.com.co/2013/06/que-son-los-living-labs.html

Savić, J. (2017). Sense(s) of the city: Cultural mapping in Porto, Portugal. City, Culture and Society, 11, Dec, pp. 12-19. Disponible en: https://www.sciencedirect.com/science/ article/pii/S1877916617301674

Silva, T.A. (2004). Imaginarios urbanos: Hacia el desarrollo de un urbanismo desde los ciudadanos. Metodología. Bogotá. Convenio Andrés Bello. Universidad Nacional de Colombia.

Silva, T.A. (2007). Imaginarios urbanos en América Latina: urbanismos.

ciudadanos. Barcelona: Fundación Antoni Tápies.

Silva T, A. (20 de febrero de 2015). Entrevista realizada a Armando Silva. Bogotá. Entrevistadora: Andreina Seijas. 
Valencia L, V. y Jaramillo N, C. (2014). Estado de la cuestión de los estudios de ciudad: el caso de las vertientes de la antropología urbana en México y Colombia / GICE. XII Congreso Latinoamericano de Investigadores de la Comunicación. Pontificia Universidad Católica del Perú, Lima, Perú. Disponible en: http://congreso.pucp.edu.pe/ alaic2014/wp-content/uploads/2013/09/vGT15-Valencia-Jaramillo.pdf

Watzlawick (1988). El ojo del observador: Contribuciones al constructivismo. Barcelona: Gedisa.

\section{Referencias complementarias}

Bedoya, O., Castiblanco, A. Jaramillo, C. (2005). Paradoja de la Ciudadanía en Pereira: Entre los Ciudadanos Jurídicos y los Ciudadanos Itinerantes (2001 - 2003). Bogotá: Tercer mundo editores.

Stelzle, B. y Rainer-Noennig, J. (2017). A Database for Participation Methods in Urban Development. Procedia Computer Science, 112, pp. 2416-2425. Disponible en: https:// www.sciencedirect.com/science/article/pii/S1877050917315302

Fischer, H. (1997). El final de los grandes proyectos. Barcelona: Gedisa.

García, Néstor. Consumidores y Ciudadanos: conflictos multiculturales de la globalización. Editorial Grijalbo S.A. de C.V. México.

--------, Culturas Híbridas: Estrategias para entrar y salir de la modernidad.1989. Random House Mondadori, S.A de C.V. México

George Balandier (1969). El Poder en escenas. De la representación del poder al poder de la representación. Ediciones Paidós, Barcelona.

Lefebvre, Henri (1971). De lo rural a lo urbano. Ediciones Península. Barcelona.

Licona (2003). Ernesto Licona Valencia (2003). Dibujos de un barrio: entre el signo y el icono, una reflexión sobre imaginarios urbanos. En Territorios ilimitados: el imaginario y sus metáforas. Universidad Autónoma Estado de Morelos. México DF.

Morin, E. (1990). Introducción al pensamiento complejo. Barcelona: Gedisa, Capra.

Niklas, Luhmann (1998). Sistemas Sociales. Lineamientos para una teoría general. Anthropos, Barcelona. 
Novikov, A. (2017). Consultado en: https://www.youtube.com/watch?v=yoSqojO2CQ\&pbjreload=10 [Fecha de consulta: 12/02/2014].

Pintos, Juan Luis (1995). Los imaginarios Sociales. La nueva construcción de la realidad social. Santander: Sal Térrea, España.

Putnam, H. (1988). Representación y realidad. Un balance crítico del funcionalismo. Barcelona: Gedisa.

Reguillo, R. (2005). Ciudad riesgo y malestares. Hacia una antropología del acontecimiento. En Canclini, N.G. (coord). La antropología urbana en México (pp. 307 340). México: Fondo de Cultura Económica.

Signorelli, A. (1981). Antropología urbana. Barcelona: Anthropos.

Torres T. Rosa (2005). Los Mass Media: Una vía de recreación del imaginario social, el caso del proyecto de renovación urbana en Pereira”. Tesis de grado, Pereira, Universidad Tecnológica de Pereira.

Valencia L. V. (2005). Pereira Recreada Desde El Imaginario Del Que Escribe En La Prensa Local: Una Mirada Desde El Lenguaje (La Tarde Y El Diario Del Otún 2001 2003) Tesis de grado, Pereira, Universidad Tecnológica de Pereira.

Varela, Francisco (1988). Conocer. Las ciencias cognitivas: tendencias y perspectivas. Cartografía de las ideas actuales. Barcelona: Gedisa, 1990.

Vélez C. (2005). La Intervención Social: Problematización del caso Pereira. Tesis de grado, Pereira, Universidad Tecnológica de Pereira.

Vellaneda B. María Paola, (2005). La Ciudad Planeada / La Ciudad No Planeada. Tesis de grado, Pereira, Universidad Tecnológica de Pereira. 

Este libro terminó de diagramarse en Septiembre de 2018, en el Centro de Recursos Informativos y Educativos de la UTP, bajo el cuidado de los autores.

Pereira, Risaralda, Colombia. 

Los lectores del presente texto, encontraran una narrativa que funde los resultados de investigaciones anteriores (2009-2017) sobre la ciudad, titulada Pereira Imaginada (muy breve dado que en el libro con el mismo nombre se presentaron los resultados ampliamente), y una estrategia de socialización-apropiación-consulta de dichos contenidos, titulada Croquis Digitales: urbanismos ciudadanos en Pereira.

En cuanto a las investigaciones, sólo damos un breve resumen, como enlace para que se comprenda el origen de la estrategia, pues existe un libro, "Pereira Imaginada" y tesis de maestría que recogen en su totalidad los resultados de la indagación.

La estrategia de divulgación-apropiación-consulta, es una plataforma multimedial que contiene las percepciones de los ciudadanos sobre las cualidades, calificaciones, escenarios, temporalidades, marcas, rutinas, y otredades sobre la ciudad de Pereira, expuesta a través de fotografías, videos, sonidos. Así mismo, se inserta el formulario base de las ciudades imaginadas, metodología tomada de los Imaginarios Urbanos propuesto por el investigador colombiano, Armando Silva (2005) con el objetivo de seguir obteniendo información de la ciudad, a medida que se navega por la plataforma. Su forma estética es amigable para el usuario: http://pereiraimaginada.utp.edu.co/(al entrar puede dar clic en X, para evitar la explicación que esta en el video); que muestran videos sobre los croquis.

En general en YouTube con la frase Pereira Imaginada, encontraran las producciones y visualizaciones de los croquis. Allí podremos observar, las dinámicas, cambios de la ciudad y sus urbanismos, lo que se convierte en memoria de ciudad, en estos momentos de tanta volatilidad de la vida urbana.

Teóricamente, los conceptos del investigador Armando Silva como, imaginarios urbanos, fantasmas, emblemas ciudadanos, croquis (imágenes mentales y afectivas de lugares, personajes, situaciones, vivencias, evocaciones), las cualidades, calificaciones, escenarios, temporalidades, marcas, rutinas, y otredades, han sido la base para comprender y organizar la información de la ciudad. 